\title{
One-year observations of carbonaceous and nitrogenous components and major ions in the aerosols from subtropical Okinawa Island, an outflow region of Asian dusts
}

\author{
B. Kunwar ${ }^{1,2}$ and K. Kawamura ${ }^{1}$ \\ ${ }^{1}$ Institute of Low Temperature Science, Hokkaido University, N19 W8, Kita-ku, Sapporo, Japan \\ ${ }^{2}$ Graduate School of Environmental Science, Hokkaido University, N11 W5, Kita-ku, Sapporo, Japan \\ Correspondence to: K. Kawamura (kawamura@lowtem.hokudai.ac.jp)
}

Received: 24 April 2013 - Published in Atmos. Chem. Phys. Discuss.: 23 August 2013

Revised: 12 December 2013 - Accepted: 7 January 2014 - Published: 17 February 2014

\begin{abstract}
Ambient aerosol samples (TSP, $n=50$ ) were collected for 12 months at subtropical Okinawa Island, Japan, an outflow region of Asian dusts in the western North Pacific and analysed for organic carbon (OC), elemental carbon (EC), water-soluble organic carbon (WSOC), water-soluble total nitrogen (WSTN), water-soluble organic nitrogen (WSON) and major ions to better understand the formation and transformation of East Asian aerosols during long-range atmospheric transport. Concentration ranges of these components are; OC: $0.76-7.1 \mu \mathrm{g} \mathrm{m}^{-3}$ (av. $1.7 \pm 1.0 \mu \mathrm{g} \mathrm{m}^{-3}$ ), EC: $\quad 0.07-0.96 \mu \mathrm{g} \mathrm{m}^{-3} \quad\left(0.28 \pm 0.19 \mu \mathrm{g} \mathrm{m}^{-3}\right)$, WSOC: $0.27-1.9 \mu \mathrm{g} \mathrm{m}^{-3} \quad\left(0.73 \pm 0.38 \mu \mathrm{g} \mathrm{m}^{-3}\right), \quad$ WSTN: 0.77 to $3.0 \mu \mathrm{g} \mathrm{m}^{-3} \quad\left(0.58 \pm 0.46 \mu \mathrm{g} \mathrm{m}^{-3}\right)$ and WSON: $0.0-$ $2.2 \mu \mathrm{g} \mathrm{m}^{-3}\left(0.12 \pm 0.23 \mu \mathrm{g} \mathrm{m}^{-3}\right)$. Higher OC concentrations were obtained in active biota seasons; spring (av. $\left.2.4 \mu \mathrm{g} \mathrm{m}^{-3}\right)$ and summer $\left(1.8 \mu \mathrm{g} \mathrm{m}^{-3}\right)$. EC and WSOC concentrations maximized in spring (av. $0.41 \mu \mathrm{g} \mathrm{m}^{-3}$ and $0.95 \mu \mathrm{g} \mathrm{m}^{-3}$, respectively) followed by winter $(0.70$ and $\left.0.90 \mu \mathrm{g} \mathrm{m}^{-3}\right)$ whereas they became lowest in summer $(0.19$ and $\left.0.52 \mu \mathrm{g} \mathrm{m}^{-3}\right)$. In contrast, WSTN concentrations were highest in winter $\left(0.86 \mu \mathrm{g} \mathrm{m}^{-3}\right)$ and lowest in summer $\left(0.37 \mu \mathrm{g} \mathrm{m}^{-3}\right)$ and autumn $\left(0.34 \mu \mathrm{g} \mathrm{m}^{-3}\right)$. Concentrations of WSON are higher in early summer (av. $0.26 \mu \mathrm{g} \mathrm{m}^{-3}$ ) due to the emission from marine biota. The high ratios of OC/EC (av. 7.6) and WSOC/OC (44\%) suggest a secondary formation of organic aerosols. Strong correlation between OC and $\mathrm{MSA}^{-}(0.81)$ in spring suggests that springtime aerosols are influenced by additional marine and terrestrial biogenic sources. The positive correlation of $\mathrm{Ca}^{2+}$ and TSP in spring $(r=0.81)$ demonstrates a significant contribution
\end{abstract}

of Asian dust whereas high abundances of $\mathrm{NO}_{3}^{-}$and nss$\mathrm{SO}_{4}^{2-}$ in winter suggest an important contribution from anthropogenic sources including biomass burning, vehicular emission and coal combustion. $\mathrm{NH}_{4}-\mathrm{N} / \mathrm{WSTN}$ ratios peaked in winter (0.56), indicating a significant contribution of biomass burning to WSTN in cold season. In contrast, higher $\mathrm{NO}_{3}$-N/WSTN ratio in spring than winter suggests that the atmospheric transport of vehicular emissions maximizes in spring. Correlation analyses of major ions suggest that $\mathrm{NH}_{4}^{+}$ and $\mathrm{Ca}^{2+}$ play major role in the neutralization of acidic aerosols forming $\mathrm{NH}_{4} \mathrm{HSO}_{4},\left(\mathrm{NH}_{4}\right)_{2} \mathrm{SO}_{4}$ and $\mathrm{CaSO}_{4}$.

\section{Introduction}

Aerosols affect the Earth's radiative forcing directly by scattering and absorbing light and indirectly by acting as cloud condensation nuclei (Buseck and Posfai, 1999). The role of atmospheric aerosols in radiative budget, however, has not been well understood despite many studies (e.g. Ramanathan et al., 2001). Carbonaceous aerosols play major role in climate change and health effect (Folinsbee, 1992). Although EC is minor component in carbonaceous aerosols, it has positive radiative forcing at the top of the atmosphere (TOA) and negative radiative forcing at the surface (Ramanathan et al., 2001). Organic aerosols that contain water-soluble species play an important role in climate forcing (Novakov and Penner, 1993) and cloud condensation nuclei (CCN) activity (Saxena et al., 1995). Large amounts of water-soluble organic compounds including dicarboxylic acids are present in the 


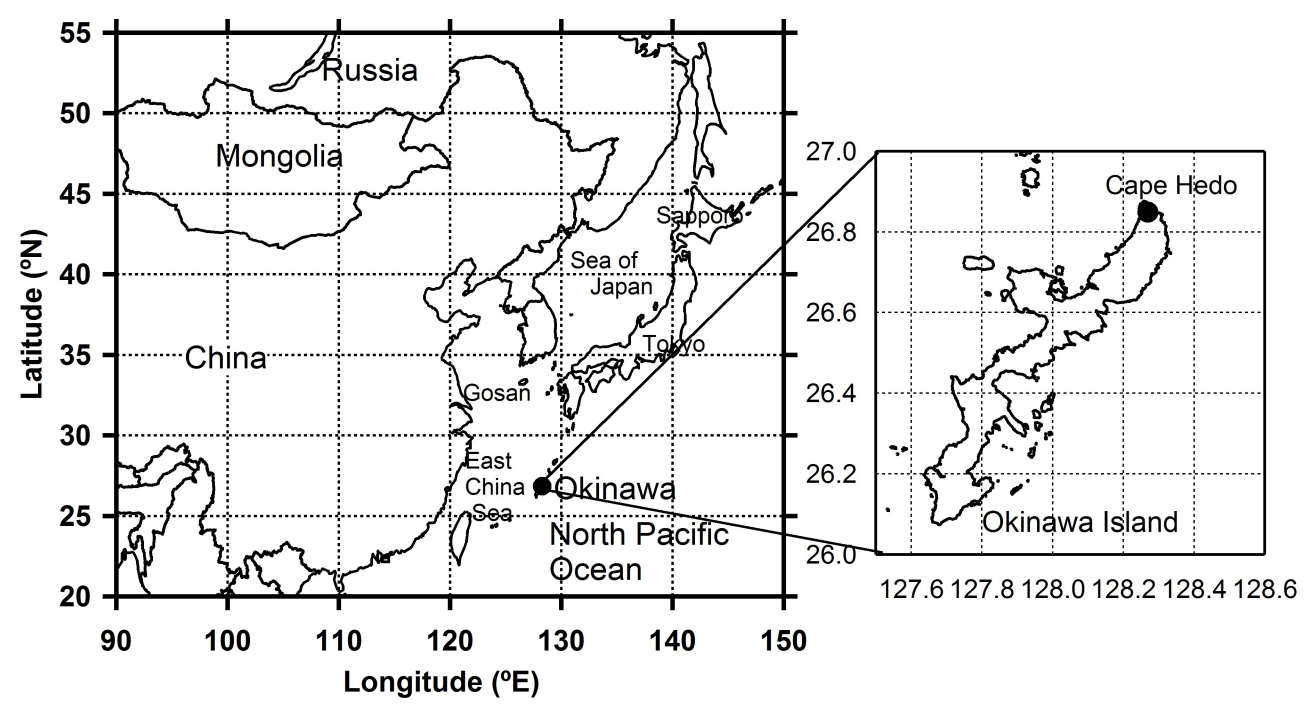

Fig. 1. Map showing the geographical region of Cape Hedo, Okinawa, where sampling was performed.

tropospheric aerosols from urban (Kawamura and Kaplan, 1987), rural (Limbeck et al., 2001), marine (Kawamura et al., 2004), Arctic (Kawamura et al., 1996a, 2010) and Antarctic regions (Kawamura et al., 1996b), supporting that they are important chemical constituents in the atmosphere.

About one fourth of the global anthropogenic carbonaceous aerosols are emitted from China, $70 \%$ of which are originated solely from coal burning (Cooke et al., 1999). Large amounts of low quality coal are used for house heating and cooking purposes (Wang et al., 2006). Light absorbing $\mathrm{EC}$ and light scattering OC have been abundantly reported in Chinese aerosols (Ho et al., 2007; Cao et al., 2007), which are subjected to long-range transport over the western North Pacific. Okinawa Island is located in the outflow region of Asian aerosols and on the pathway to the Pacific. Cape Hedo is located on the northern edge of Okinawa and has been used as a supersite of Atmospheric Brown Clouds (ABC) project to study the atmospheric transport of Chinese aerosols and their chemical transformation in East Asia (Takami et al., 2007). In the Asian Pacific region, the East Asian monsoon dominates in winter to spring, whereas the monsoon from the Pacific Ocean dominates in summer to fall (Sato et al., 2009), therefore, continental air masses from East Asian countries including Russia, Mongolia, China, and Korea generally arrive over Okinawa during winter and spring.

In this study, we report one-year observations of OC, EC, WSOC, WSTN and major ions in ambient atmospheric aerosols collected at Cape Hedo, Okinawa. We calculate water-soluble organic nitrogen (WSON) based on the difference between WSTN and inorganic nitrogen $\left(\mathrm{NO}_{3}^{-}\right.$and $\mathrm{NH}_{4}^{+}$). We discuss the seasonal changes of these components and transformations of organic aerosol (OA) during the longrange transport of Asian aerosols. Many studies related to the atmospheric chemistry have been conducted at Cape Hedo
(Sato et al., 2009; Wang et al., 2009; Zhang et al., 2003; Jaffe et al., 2005; Verma et al., 2011; Lun et al., 2009; Yamamoto and Kawamura, 2011; Ueda et al., 2011; Arakaki et al., 2006; Handa et al., 2010; Mochida et al., 2010). However, no studies were conducted for a long-term measurement of OC, EC, WSOC, WSTN, WSON and major ions in atmospheric aerosols from Cape Hedo, Okinawa Island.

\section{Samples and analytical procedure}

\subsection{Sampling site and aerosol collection}

Using a high-volume air sampler (Kimoto AS-810B) and pre-combusted $\left(450^{\circ} \mathrm{C}, 4 \mathrm{~h}\right)$ quartz fiber filters (Pallflex 2500QAT, $20 \times 25 \mathrm{~cm}$ ), total suspended aerosol (TSP) samples $(n=50)$ were collected on weekly basis at Cape Hedo Atmosphere and Aerosol Measurement Station (CHAAMS, $26^{\circ} 9^{\prime} \mathrm{N}, 128^{\circ} 2^{\prime} \mathrm{E}$ ) from 2009 October to 2010 October. The sampling period of each sample was 7 days. Figure 1 shows a map of East Asia with the geographical location of Cape Hedo in Okinawa. CHAAMS is located at the northwestern part of Okinawa Island, Japan and it is surrounded by subtropical forest (Yamamoto and Kawamura, 2011) where local anthropogenic emissions are insignificant (Takami et al., 2007). Aerosol filter samples were placed in a preheated glass jar $(150 \mathrm{~mL})$ with a Teflon-lined screw cap and stored in darkness at $-20^{\circ} \mathrm{C}$ until the analysis. Field blanks were also collected at the site. Blank filter was placed in the filter cartridge of sampler without pumping air. After $10 \mathrm{~s}$, field blank filter was recovered from the cartilage. Quartz fiber filters may adsorb organic vapours, causing positive artefacts on OC measurements. However, due to the relatively long sampling period (one week), we consider that the artefacts may be minimal. 


\subsection{Chemical analysis}

Before the analysis, TSP mass was gravimetrically determined at room temperature of $20^{\circ} \mathrm{C}$ and $50 \%$ relative humidity. However, the TSP mass may be overestimated due to the water contained in the marine aerosol filters. OC and EC were measured using a Sunset Laboratory carbon analyser following Interagency Monitoring Protected Visual Environments (IMPROVE) thermal/optical evolution protocol (Wang et al., 2005). Presence of carbonate carbon is assumed to be negligible, except for two spring samples, which showed that the $\mathrm{pH}$ of the filter extracts were alkaline. A filter disk $\left(1.5 \mathrm{~cm}^{2}\right.$ punch $)$ was put in quartz boat inside the thermal desorption chamber and stepwise heating was applied in a helium flow at first and then after the initial ramp, helium gas was switched to $\mathrm{He} / \mathrm{O}_{2}$. The evolved $\mathrm{CO}_{2}$ during the oxidation at each temperature step was measured with non-dispersive infrared (NDIR) detector system. The transmittance of light (red $660 \mathrm{~nm}$ ) through the filter punch was used for setting up OC/EC split point and thereby OC correction. The analytical errors in duplicate analysis of the filter sample were less than $8 \%$ for OC and $5 \%$ for EC. OC and EC concentrations reported here are corrected for the field blanks.

WSOC and WSTN were determined using a Shimadzu carbon/nitrogen analyser (TOC- $\mathrm{V}_{C S H}$ ) (Miyazaki et al., 2011). A filter disc $\left(3.14 \mathrm{~cm}^{2}\right)$ was extracted with organicfree pure water under ultrasonication for 15 minutes. The water extracts were filtrated on a syringe filter (Millex-GV, $0.45 \mu \mathrm{m}$, Millipore). Before the analysis, the extracts were acidified with $1.2 \mathrm{M} \mathrm{HCl}$ and purged with pure air to remove dissolved inorganic carbon and volatile organics. The analytical error in triplicate analysis of laboratory standards was within 5\% (Miyazaki et al., 2011).

Major cations and anions were measured using an ion chromatograph (761 Compact IC, Metrohm, Switzerland). A sample filter disc (20 mm diameter) was extracted with organic-free pure water $(10 \mathrm{~mL})$ under ultrasonication (15 min $\times 2$ times). The extracts were filtrated using a membrane disc filter (Millex-GV, $0.45 \mu \mathrm{m}$, Millipore) and injected to IC for measuring major ions. Anions were separated on a SI-90 4E Shodex column (Showa Denko, Tokyo, Japan) using a mixture of $1.8 \mathrm{mM} \mathrm{Na}_{2} \mathrm{CO}_{3}$ and $1.7 \mathrm{mM} \mathrm{NaHCO}_{3}$ at a flow rate of $1.2 \mathrm{~mL} \mathrm{~min}^{-1}$ as an eluent and $40 \mathrm{mM} \mathrm{H}_{2} \mathrm{SO}_{4}$ for suppressor. For cation measurements, a Metrosep C2-150 (Metrohm) column was used by using a mixture of $4 \mathrm{mM}$ tartaric acid and $1 \mathrm{mM}$ dipicolinic acid as an eluent at a flow rate of $1.0 \mathrm{~mL} \mathrm{~min}^{-1}$. The injection loop volume was $200 \mu \mathrm{L}$. The analytical errors in duplicate analysis of the authentic standards were within $5 \%$. We determined total 11 ions including methanesulfonate $\left(\mathrm{MSA}^{-}\right)$. The detection limits for anions and cations were ca. $0.1 \mathrm{ng} \mathrm{m}^{-3}$. The field blanks for $\mathrm{Na}^{+}$ and $\mathrm{Ca}^{2+}$ are 0.078 and $0.144 \mathrm{ng} \mathrm{L}^{-1}$, respectively, whereas those for $\mathrm{MSA}^{-}, \mathrm{Cl}^{-}, \mathrm{NO}_{3}^{-}$and $\mathrm{SO}_{4}^{2-}$ were $0.003,0.01$,
0.001 and $0.011 \mathrm{ng} \mathrm{L}^{-}$, respectively. Here, we report the concentrations of all species after the blank correction.

\subsection{Estimate of organic matter and secondary organic carbon}

Abundances of organic matter (OM) in the atmosphere are generally estimated by multiplying the measured OC concentrations with the conversion factor of $1.6 \pm 0.2$ for urban and $2.1 \pm 0.2$ for aged aerosols (Turpin and Lim, 2001). As mentioned above, our sampling site is located in the outflow region of East Asian aerosols and local anthropogenic activities are negligible. During the atmospheric transport, aerosols are subjected to aging processes to result in more oxygenated organic species (Kawamura et al., 2004; Kundu et al., 2010). Thus, it is better to take $2.1 \pm 0.2$ instead of $1.6 \pm 0.2$ for the Cape Hedo samples.

The contributions of the primary and secondary organic carbon (SOC) to carbonaceous aerosols are calculated by EC-tracer method. EC is used as a tracer of incomplete combustions generated from primary sources (e.g. Turpin and Huntzicker, 1991). The EC-tracer method assumes the relatively constant $\mathrm{OC} / \mathrm{EC}$ ratios for given area, season and local meteorology because EC and primary OC (POC) typically have the same sources (Pavuluri et al., 2011). Thus, we can use the minimum $\mathrm{OC} / \mathrm{EC}$ ratios to estimate the contribution of SOC in the atmospheric aerosol for a specific region of interest (Castro et al., 1999). This method is also applied in several atmospheric researches (Turpin and Huntzicker, 1995; Castro et al., 1999; Pavuluri et al., 2011) although it involves some degree of uncertainty. In this study, the concentrations of SOC and POC were calculated by the following equations

$\mathrm{POC}=\mathrm{EC} \times(\mathrm{OC} / \mathrm{EC})_{\min }+k$

$\mathrm{SOC}=\mathrm{OC}_{\text {meas }}-\mathrm{POC}$,

where $(\mathrm{OC} / \mathrm{EC})_{\min }$ is the observed minimum $\mathrm{OC} / \mathrm{EC}$ ratio during the sampling period, $k$ is a parameter for noncombustion sources contributing to the POC that is assumed to be negligible, and $\mathrm{OC}_{\text {meas }}$ is the measured $\mathrm{OC}$ concentration. The minimum OC/EC ratios in winter, spring, summer and autumn are $3,4,5$, and 3 , respectively.

\subsection{Estimate of sea salt and non-sea salt component}

In order to determine whether it is oceanic or continental, sea salt (ss) and non-sea salt (nss) concentrations were calculated using $\mathrm{Na}^{+}$as a reference element. The mass concentrations of non-sea salt component X $\left(M_{n s s-x}\right)$ can be estimated as follows (George et al., 2008).

$M_{\mathrm{nss}-\mathrm{x}}=M_{\mathrm{x}}-(\mathrm{X} / \mathrm{Na})_{\mathrm{sw}} \times M_{\mathrm{Na}}$,

where $M_{\mathrm{X}}$ and $M_{\mathrm{Na}}$ mean the total mass loading of $\mathrm{X}$ and $\mathrm{Na}$, respectively. $(\mathrm{X} / \mathrm{Na})_{\mathrm{sw}}$ represents the mass ratio of species $\mathrm{X}$ to $\mathrm{Na}$ in seawater. The ratios of $\mathrm{X} / \mathrm{Na}$ for $\mathrm{SO}_{4}^{2-}, \mathrm{K}^{+}, \mathrm{Ca}^{2+}$ 
and $\mathrm{Mg}^{2+}$ are $0.25,0.037,0.038$ and 0.12 , respectively, assuming that sea salt is the only source of water-soluble $\mathrm{Na}^{+}$ (Berg and Winchester, 1978). By using above equation, the mass concentrations of ss- and nss- $\mathrm{SO}_{4}^{2-}, \mathrm{K}^{+}, \mathrm{Ca}^{2+}$, and $\mathrm{Mg}^{2+}$ are calculated.

\subsection{Estimate of chlorine loss}

Chlorine depletion can be estimated using following formula (Yao and Zhang, 2012).

$\mathrm{Cl}_{\text {loss }}\left(\mu \mathrm{g} \mathrm{m}{ }^{-3}\right)=1.798 \cdot\left[\mathrm{Na}^{+}\right]_{\text {measured }}-\left[\mathrm{Cl}^{-}\right]_{\text {measured }}$

$\mathrm{Cl}_{\text {loss }}(\%)=\left[\mathrm{Cl}_{\text {loss }}\right] / 1.798\left[\mathrm{Na}^{+}\right]_{\text {measured }} \cdot 100$,

where $\left[\mathrm{Na}^{+}\right]_{\text {measured }}$ and $\left[\mathrm{Cl}^{-}\right]_{\text {measured }}$ represent measured concentrations of $\mathrm{Na}^{+}$and $\mathrm{Cl}^{-}$in $\mu \mathrm{g} \mathrm{m}^{-3}$, respectively. The mass concentration ratio of $\mathrm{Cl}^{-}$to $\mathrm{Na}^{+}$in seawater is 1.798 (George et al., 2008). The following two reactions are associated with the loss process of $\mathrm{Cl}$.

$\mathrm{HNO}_{3}(\mathrm{~g})+\mathrm{NaCl}(\mathrm{p})=\mathrm{HCl}(\mathrm{g})+\mathrm{NaNO}_{3}(\mathrm{p})$

$\mathrm{H}_{2} \mathrm{SO}_{4}(\mathrm{~g})+2 \mathrm{NaCl}(\mathrm{p})=2 \mathrm{HCl}(\mathrm{g})+\mathrm{Na}_{2} \mathrm{SO}_{4}(\mathrm{p})$.

\subsection{Backward air mass trajectory analysis}

Hybrid Single-Particle Lagrangian Integrated Trajectory (HYSPLIT4) model (http://www.arl.noaa.gov/ready/ hysplit4.html) was used to find the source regions of air masses at Okinawa during one-year campaign (Draxler and Rolph, 2003). 5-day back trajectory analysis at $500 \mathrm{~m}$ above the ground was performed every day using the HYSPLIT model. Figure 2 shows the 5-day air mass trajectories for winter, spring, summer and autumn seasons. In spring and winter, Cape Hedo was strongly influenced by continental air masses (Fig. 2a and 2b). In contrast, in summer, the site was covered with oceanic air masses (Fig. 2c) whereas in autumn it was affected by both oceanic and continental air masses (Fig. 2d). As described previously, the sampling period is 7 days for each sample. Thus, each sample contains mixed air masses from continent and ocean.

\section{Results and discussion}

\subsection{Aerosols mass loading}

The aerosol mass loading at Okinawa ranged from 19.2 to $286 \mu \mathrm{g} \mathrm{m}^{-3}$ with an average of $74.3 \mu \mathrm{g} \mathrm{m}^{-3}$ during one-year observation period. Figure 3 shows the monthly averaged aerosol mass concentrations at Okinawa with error bars denoting the standard deviation. The average mass concentration shows a peak $\left(109 \pm 69.9 \mu \mathrm{g} \mathrm{m}^{-3}\right)$ during spring season (March, April and May) and decrease towards the summer $\left(44 \pm 36 \mu \mathrm{g} \mathrm{m}^{-3}\right)$. The westerly winds are responsible for such a high peak in spring, by uplifting the mineral dusts from the arid regions in China and Mongolia followed by a transport to the Pacific together with pollutants emitted from Chinese cities. During the Asian dust outflow, crustal elements (calcium, iron, aluminium, barium, etc.) are abundant in dust particles and loess deposits (Nishikawa et al., 2000). A good correlation between $\mathrm{Ca}^{2+}$ and TSP $(r=0.81)$ in spring suggests that the spring aerosols are significantly influenced by dust particles from arid regions in China and Mongolia. During spring, Asian dust is the source of $\mathrm{Ca}^{2+}$. Air mass back trajectories also demonstrated that in spring, air masses mostly originated from the arid regions of the Asian continent.

\subsection{Seasonal variations of carbonaceous and nitrogenous components}

Table 1 gives the concentrations of carbonaceous components with statistical summaries in the TSP samples $(n=$ 50) collected from Cape Hedo, Okinawa. Their monthly variations are shown in Fig. 4. The average concentrations of OC, EC, WSOC and WSTN ranged from 0.76 to $7.12 \mu \mathrm{g} \mathrm{m}^{-3}$ (av. $1.78 \mu \mathrm{g} \mathrm{m}^{-3}$ ), $0.07-0.96 \mu \mathrm{g} \mathrm{m}^{-3}$ $\left(0.28 \mu \mathrm{g} \mathrm{m}^{-3}\right) \quad 0.27-1.9 \mu \mathrm{g} \mathrm{m}^{-3} \quad\left(0.73 \mu \mathrm{g} \mathrm{m}^{-3}\right)$ and 0.07 $3.02 \mu \mathrm{g} \mathrm{m}^{-3}\left(0.58 \mu \mathrm{g} \mathrm{m}^{-3}\right)$, respectively. Seasonally average concentration of $\mathrm{OC}$ was found highest in spring $\left(2.36 \mu \mathrm{g} \mathrm{m}^{-3}\right)$ followed by summer $\left(1.79 \mu \mathrm{g} \mathrm{m}^{-3}\right)$ and winter $\left(1.53 \mu \mathrm{g} \mathrm{m}^{-3}\right)$ whereas the lowest concentration was observed in autumn $\left(1.42 \mu \mathrm{g} \mathrm{m}^{-3}\right)$. Similarly, the highest concentrations of EC and WSOC were found in spring $\left(0.41 \mu \mathrm{g} \mathrm{m}^{-3}\right.$ and $\left.0.95 \mu \mathrm{g} \mathrm{m}^{-3}\right)$ followed by winter $(0.70$ and $\left.0.90 \mu \mathrm{g} \mathrm{m}^{-3}\right)$. In contrast, the lowest concentrations of EC and WSOC were obtained in summer ( 0.19 and $0.52 \mu \mathrm{g} \mathrm{m}^{-3}$ ).

OC showed higher concentration during winter in Chinese aerosols (Wang et al., 2011; Cao et al., 2003, 2007; Ho et al., 2007) because low quality coals are commonly used for heating and cooking purposes. Very high concentration of OC was reported in winter than spring in urban regions of China (Wang et al., 2011). In contrast, we found higher concentration of OC in spring although most of the air parcels came from China, suggesting the additional contribution to OC from biogenic sources because biogenic emissions are significant in spring season (Pavuluri et al., 2010). The springtime maxima of OC (Fig. 4a) and WSOC (Fig. 4c) suggest that they are formed by extensive photochemical oxidation of various organic precursors emitted from fossil fuel combustion and biomass burning as well as biogenic volatile organic compounds (BVOCs) from terrestrial plants. EC also maximized in spring followed by winter, suggesting significant contributions of EC from China through long-range atmospheric transport by westerly winds. Water-insoluble organic carbon $(\mathrm{WIOC}=\mathrm{OC}-\mathrm{WSOC}$ ) showed the highest concentration in spring $\left(1.41 \mu \mathrm{g} \mathrm{m}^{-3}\right)$ followed by summer $\left(1.27 \mu \mathrm{g} \mathrm{m}^{-3}\right)$. 

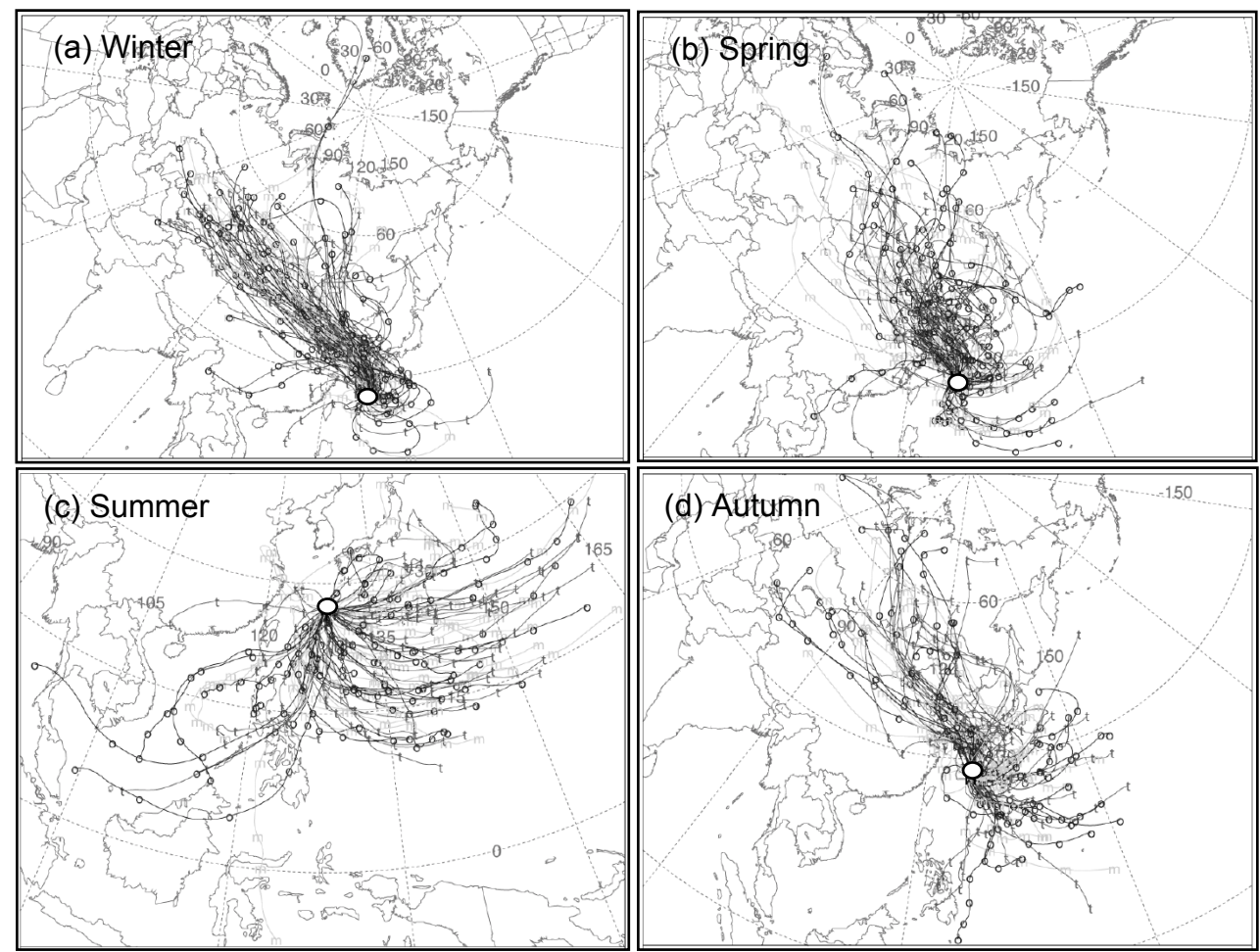

Fig. 2. Five-day backward trajectory analysis for four seasons; (a) winter (December, January and February), (b) spring (March, April and May), (c) summer (June, July and August), and (d) autumn (September, October and November). Backward trajectories at $500 \mathrm{~m}$ above ground level were drawn with the NOAA HYSPLIT model.

Table 1. Seasonal variations of mass concentrations of different organic components in aerosols from Cape Hedo, Okinawa.

\begin{tabular}{l|cc|cc|ccc|cc}
\hline & \multicolumn{10}{c}{ Concentration in $\left(\mu \mathrm{g} \mathrm{m}^{-3}\right)$} \\
\hline \multirow{2}{*}{ Components } & \multicolumn{2}{c}{ Spring } & \multicolumn{2}{c}{ Summer } & \multicolumn{2}{c}{ Autumn } \\
& \multicolumn{2}{c}{ Range } & AV \pm SD & Range & AV \pm SD & Range & AV \pm SD & Range & AV \pm SD \\
\hline OC & $0.83-2.49$ & $1.53 \pm 0.51$ & $1.04-7.12$ & $2.36 \pm 1.71$ & $0.84-3.01$ & $1.79 \pm 0.56$ & $0.76-2.52$ & $1.42 \pm 0.48$ \\
EC & $0.14-0.59$ & $0.70 \pm 0.51$ & $0.19-0.96$ & $0.41 \pm 0.24$ & $0.07-0.54$ & $0.19 \pm 0.14$ & $0.09-0.38$ & $0.20 \pm 0.09$ \\
WSOC & $0.45-1.37$ & $0.90 \pm 0.29$ & $0.53-1.88$ & $0.95 \pm 0.40$ & $0.27-1.90$ & $0.52 \pm 0.42$ & $0.29-0.70$ & $0.55 \pm 0.18$ \\
WIOC & $0.08-1.12$ & $0.63 \pm 0.25$ & $0.51-5.24$ & $1.41 \pm 1.34$ & $0.57-2.29$ & $1.27 \pm 0.41$ & $0.37-1.84$ & $0.89 \pm 0.51$ \\
OM & $1.66-4.98$ & $3.05 \pm 1.02$ & $2.07-14.2$ & $4.72 \pm 3.42$ & $1.68-6.02$ & $3.59 \pm 1.12$ & $1.52-5.04$ & $2.85 \pm 0.95$ \\
WSOM & $0.90-2.74$ & $1.80 \pm 0.58$ & $1.06-3.76$ & $1.91 \pm 0.81$ & $0.54-3.80$ & $1.05 \pm 0.85$ & $0.57-1.81$ & $1.12 \pm 0.41$ \\
WIOM & $0.16-2.24$ & $1.26 \pm 0.51$ & $1.02-10.4$ & $2.82 \pm 2.69$ & $1.14-4.59$ & $2.54 \pm 0.82$ & $0.75-3.69$ & $1.73 \pm 0.81$ \\
POC & $0.63-1.17$ & $1.08 \pm 0.40$ & $0.56-2.12$ & $1.60 \pm 0.98$ & $0.35-2.71$ & $0.93 \pm 0.68$ & $0.25-2.80$ & $0.59 \pm 0.28$ \\
SOC & $0.17-0.71$ & $0.44 \pm 0.13$ & $0.12-3.60$ & $0.74 \pm 0.93$ & $0.30-1.36$ & $0.86 \pm 0.39$ & $0.08-2.60$ & $0.84 \pm 0.57$ \\
\hline
\end{tabular}

EC and WSOC show similar seasonal variations (Fig. 4b, c), suggesting that they are formed from similar sources. The average highest concentration of primary organic carbon (POC) is found in spring followed by winter whereas the higher concentration of secondary organic carbon (SOC) was found in spring and summer, as shown in Fig. 4e and 4f. The highest concentration of SOC was observed in March with an increase toward July. The average highest concentration of SOC in summer may be caused by photochemical oxidation of organic precursors under a strong solar radiation as well as emission of marine volatile organic carbon (Shaw et al., 2010). The higher wind speed during spring may be responsible for higher POC concentration.

WSTN showed higher concentrations during winter $\left(0.86 \mu \mathrm{g} \mathrm{m}^{-3}\right)$ followed by spring $\left(0.77 \mu \mathrm{g} \mathrm{m}^{-3}\right)$ although the concentrations during spring months are almost constant whereas they showed lower concentrations during summer and autumn $\left(0.37\right.$ and $\left.0.34 \mu \mathrm{g} \mathrm{m}^{-3}\right)$. The higher concentration of WSTN during winter suggests that WSTN is abundantly present in polluted air. Meanwhile, concentrations 


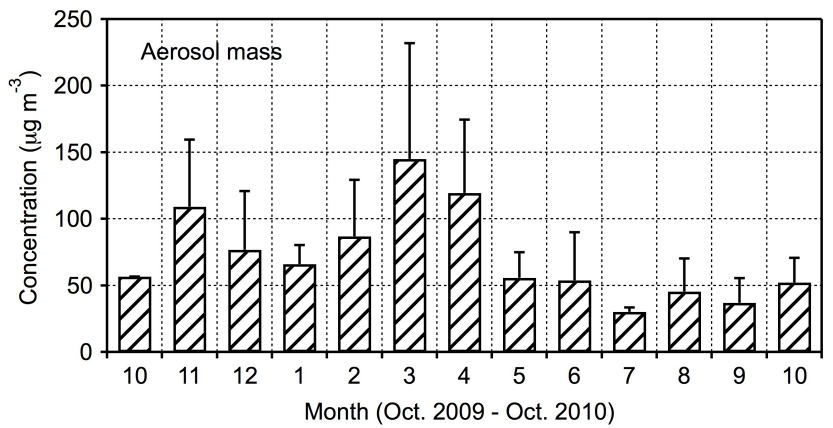

Fig. 3. Average monthly variation of aerosol mass loading in ambient aerosols collected in Cape Hedo, Okinawa.

of water-soluble organic nitrogen $\left(\mathrm{WSON}=\mathrm{WSTN}-\mathrm{NO}_{3}\right.$ $\mathrm{N}-\mathrm{NH}_{4}-\mathrm{N}$ ) ranged from 0 to $2.2 \mu \mathrm{g} \mathrm{m}^{-3}$ (av. $0.11 \mu \mathrm{g} \mathrm{m}{ }^{-3}$ ). WSON comprised on average $18.9 \%$ of WSTN. Marine organisms are probably the main sources of WSON. Terrestrial and marine organisms emit nitrogenous components, which contain certain amount of WSON (Wang et al., 2013a). Marine bacteria and degraded proteins are the sources of WSON (Wedyan and Preston, 2008). Marine biota also can emit amino acids, urea and proteins. WSON is emitted to the atmosphere by bubble bursting process in the ocean surface (Cape et al., 2011). We found the highest concentration of WSON in summer (av. $0.21 \mu \mathrm{g} \mathrm{m}^{-3}$ ) followed by spring $(0.13)$ and autumn (0.07) and lowest concentration in winter (0.06). The summertime maximum of WSON suggests that they are emitted from marine biota.

We found that the contribution of OM to TSP is on average $6.27 \pm 3.7 \%$. The highest average contribution of OM to TSP was found in summer $(9.5 \%)$ followed by autumn $(5.31 \%)$ and spring $(4.85 \%)$, and the lowest $(4.48 \%)$ in winter (Fig. 5). The contribution of WSOM to TSP was found highest in winter $(2.71 \%)$ followed by summer $(2.60 \%)$. In contrast, the contribution of WIOM (water insoluble organic matter) to TSP became highest in summer (6.9\%), suggesting more emission of WIOM in summer probably from biological sources (Miyazaki et al., 2011). The average contribution of EC to TSP was found highest in winter $(0.54 \%)$, and lowest in summer $(0.42 \%)$. In this study, a strong correlation was found between OC and EC in winter $(r=0.93)$ and spring (0.81), suggesting that they are formed from similar sources (Turpin et al., 1991). However, such a strong relation was not found in summer (0.44) (Fig. 6), indicating that OC has at least two independent sources that distort the correlation. During winter and spring, our sampling site is significantly influenced by the outflow of polluted air masses from East Asian countries, thus we obtained strong correlation between OC and EC. However, in summer, anthropogenic contributions are negligible in Cape Hedo, hence the correlation between OC and EC is rather weak.
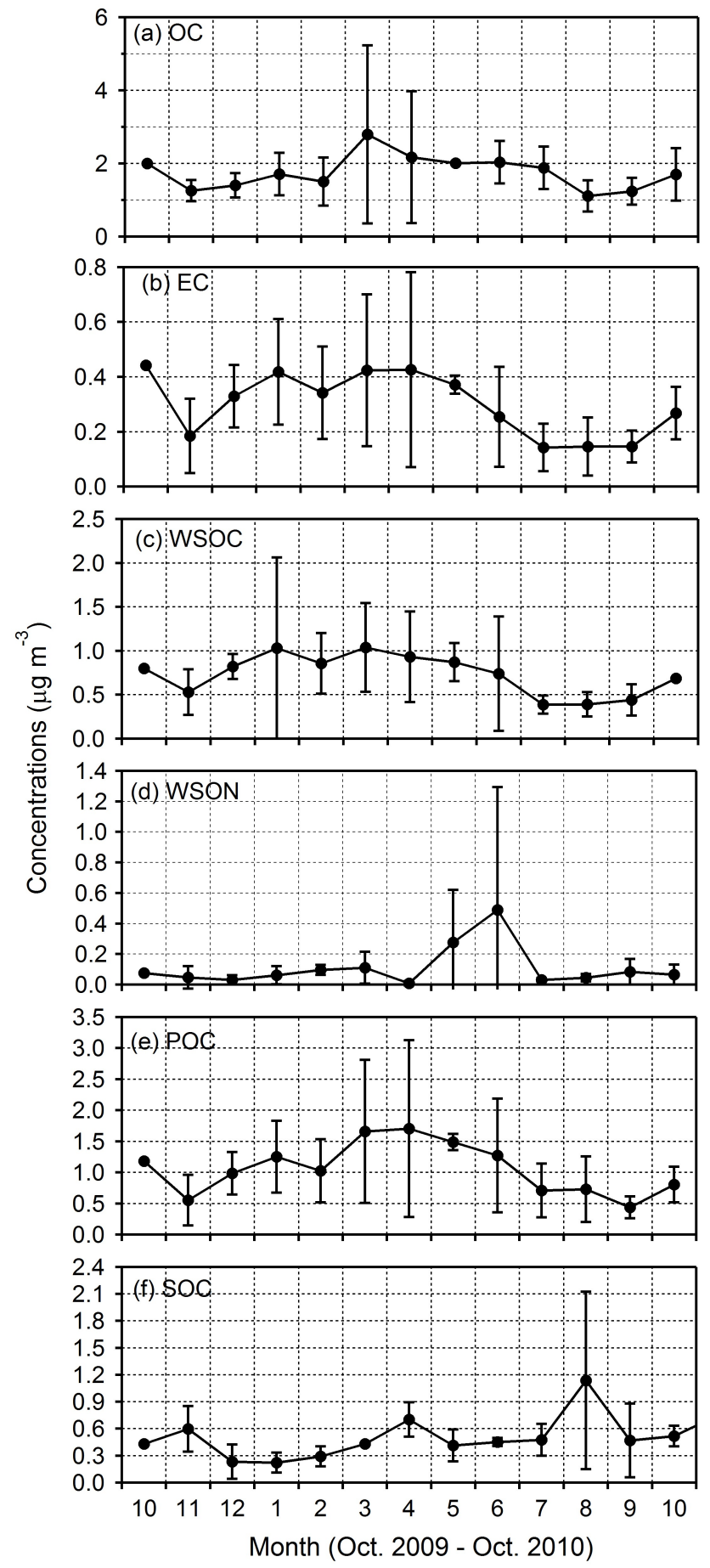

Fig. 4. Seasonal variation in concentrations of (a) organic carbon (OC), (b) elemental carbon (EC), (c) water soluble organic carbon (WSOC), (d) water soluble organic nitrogen (WSON), (e) primary organic carbon (POC), and (f) secondary organic carbon (SOC) in ambient aerosols collected in Cape Hedo, Okinawa. 
(a) Winter

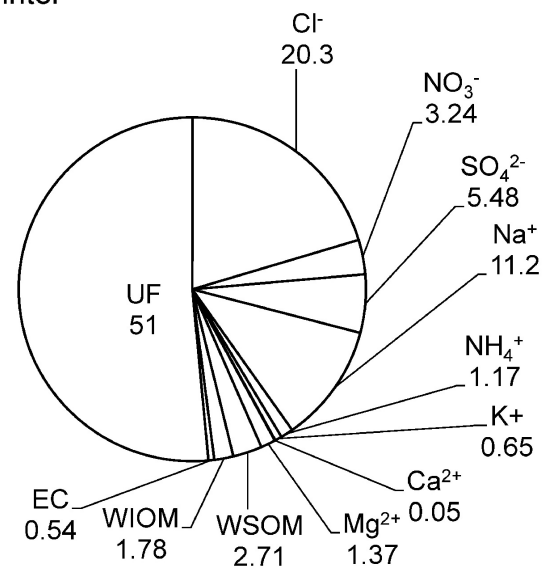

(c) Summer

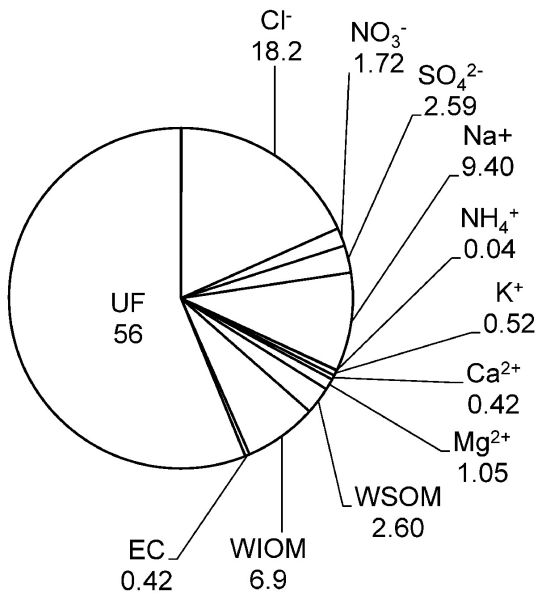

(b) Spring

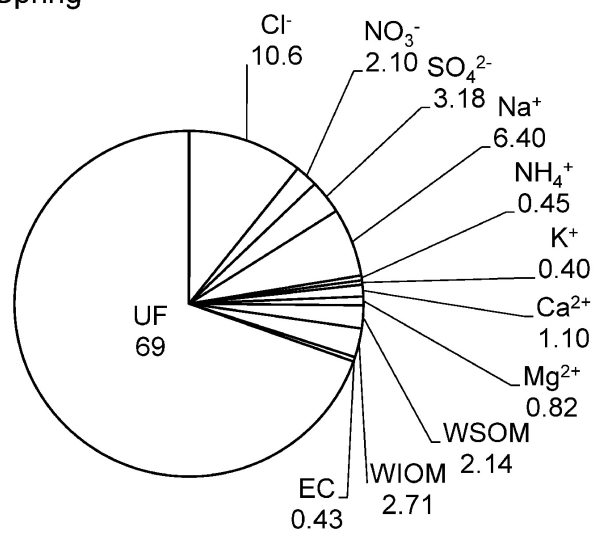

(d) Autumn

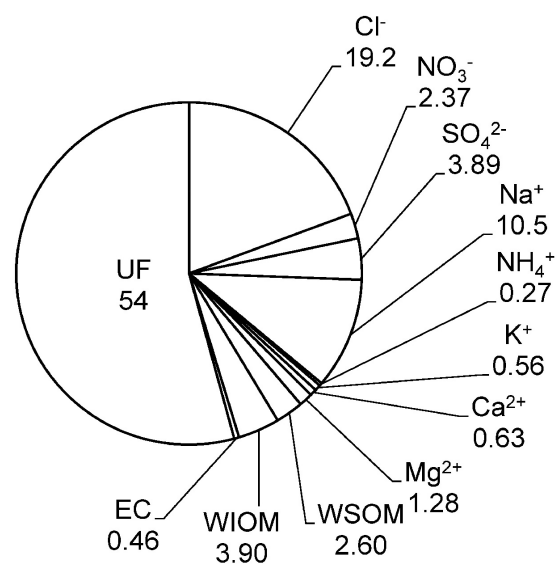

Fig. 5. Average relative abundances (\%) of water-soluble organic matter (WSOM), water insoluble organic matter (WIOM), elemental carbon (EC), and major ions in ambient aerosols collected in Cape Hedo, Okinawa. UF is unanalysed fraction.

\subsection{Seasonal variations of $\mathrm{OC} / \mathrm{EC}$ and WSOC / OC ratios}

OC / EC ratio has been used to study the emission and transformation characteristics of carbonaceous aerosols (Cao et al., 2003). The OC/EC ratios exceeding 2.0 have been considered to indicate the contribution of secondary organic aerosols (Cao et al., 2003). In our study, OC/EC ratios ranged from 3.5 to 21 with average of $7.6 \pm 4.7$. The seasonaveraged OC/EC ratios are 4.4 (winter), 5.7 (spring), 12.5 (summer) and 7.7 (autumn). Most of the world's urban OC $/ \mathrm{EC}$ ratios range from 1 to 4 (Turpin et al., 1991). A ratio of 4.0 is also assumed for emissions from fossil fuel combustion (Koch, 2001). The average ratio is still higher in spring than winter although EC showed higher concentration in spring. The OC/EC ratios obtained in this study, except for summer samples, are comparable to those from Mongolia and Chinese cities (Jung et al., 2010; Cao et al., 2007). Compared to the world's urban OC/EC ratios, our summer $\mathrm{OC} / \mathrm{EC}$ ratio (12.5) is extremely high, suggesting an extra source of OC from the ocean and/or secondary OC formation via the oxidation of BVOCs in summer. Tambunan et al. (2006) showed that the emissions of isoprene and other BVOCs maximize in Okinawa during summer. Generally, their emissions are higher in summer (Kim et al., 2005).

Figure $7 \mathrm{a}$ shows the monthly variation of $\mathrm{OC} / \mathrm{EC}$ ratios. In November we obtained relatively high OC/EC ratio. This may be caused by long-range atmospheric transport of biomass burning plumes from Southeast Asia because biomass burning is very common in the region in autumn (Wang et al., 2013b) and the air masses mostly came from Southeast Asia including Philippines (Fig. 2d). OC/EC ratios from biomass burning give higher values of 5 to 8 (Andreae and Merlet, 2001). We found a strong correlation $(r=0.87)$ between OC and biomass burning tracer $\left(n s s-\mathrm{K}^{+}\right)$ in autumn, indicating a significant influence of biomass burning on organic aerosols. The enhanced OC/EC ratios were found in summer with a peak in July. The summer maximum may be caused by the secondary formation of OC via the oxidation of various VOCs during long-range atmospheric 

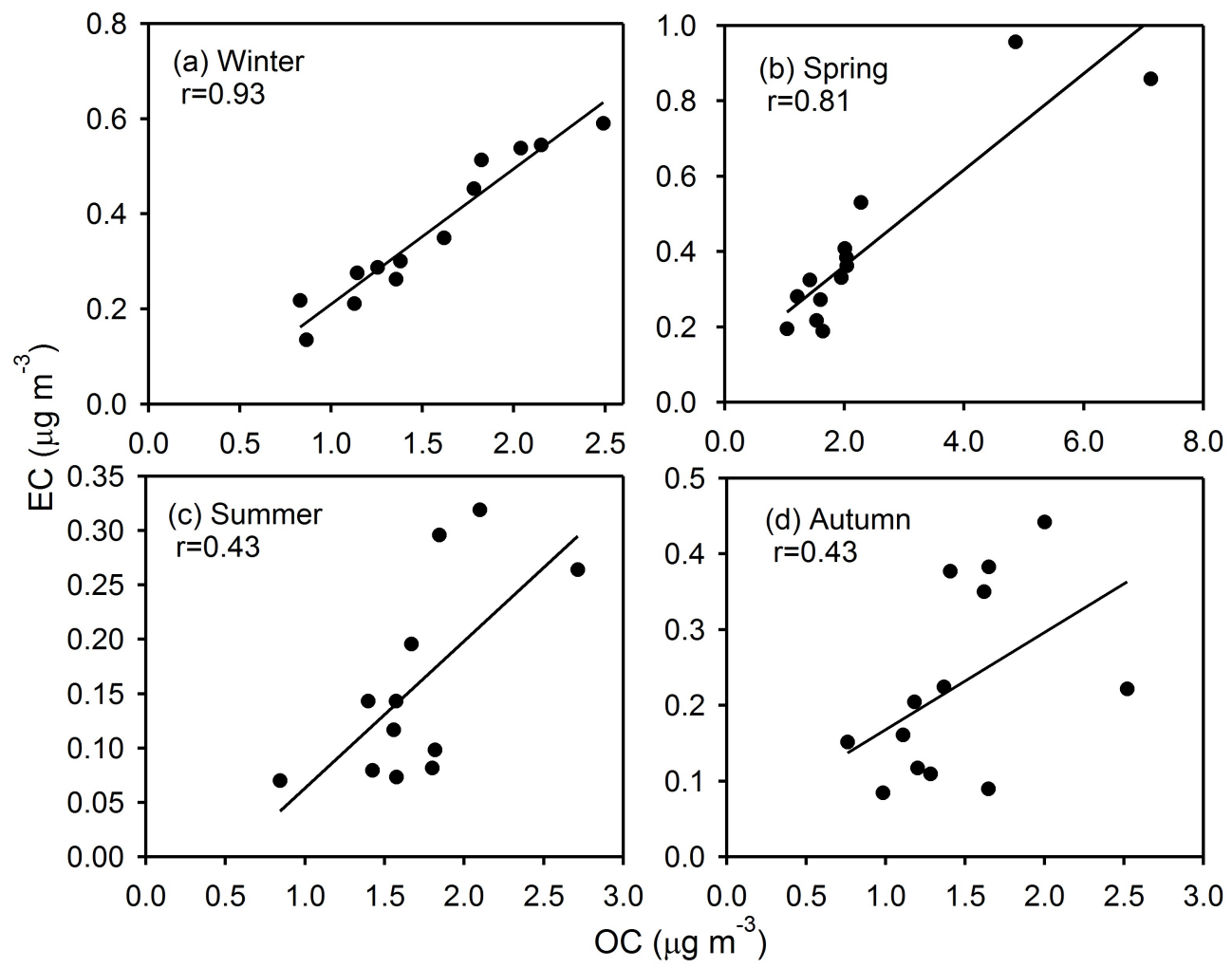

Fig. 6. Correlation analysis between elemental carbon (EC) and organic carbon (OC) in ambient aerosol samples collected from Cape Hedo Okinawa.

transport. Cao et al. (2005) showed that aerosols from residential coal combustion contain high $\mathrm{OC} / \mathrm{EC}$ ratio (12). The average OC / EC ratios for winter (4.4) and spring (5.7) samples are comparable with the value (3.8) reported in 14 Chinese cities (Cao et al., 2007), indicating that our sampling site is significantly influenced by anthropogenic aerosols from China.

WSOC to OC ratio is useful to discuss the potential sources (Jung et al., 2010) and to understand photochemical oxidation (Miyazaki et al., 2010b) and extent of gas to particle formation of secondary WSOC (Hagler et al., 2007). Figure $7 \mathrm{~b}$ shows the monthly averaged variation of WSOC/OC. The annual average ratio in Cape Hedo was $43 \pm 15 \%$ (range, 15 to $90 \%$ ). This value is lower than the ratios reported in Mongolian aerosols (31-97\%, av. 53\%) (Jung et al., 2010), Christchurch, New Zealand (48\%, Wang et al., 2005) but similar to those from Sapporo, Japan (44\%, Aggarwal and Kawamura, 2008) and from 14 Chinese cities (summer $48 \%$ and winter $40 \%$, Ho et al., 2007). However, lower WSOC/OC ratios were reported from Gosan, Korea (30\%) during the ABC campaign (Miyazaki et al., 2007), from New Delhi, India (25\%) in nighttime (Miyazaki et al., 2009), and from Tokyo (summer $20 \%$ and winter $35 \%$, Miyazaki et al., 2006). Mayol-Bracero et al. (2002) reported higher WSOC/OC ratios (45-75\%) in biomass burning aerosols over Amazonia. The smouldering biomass
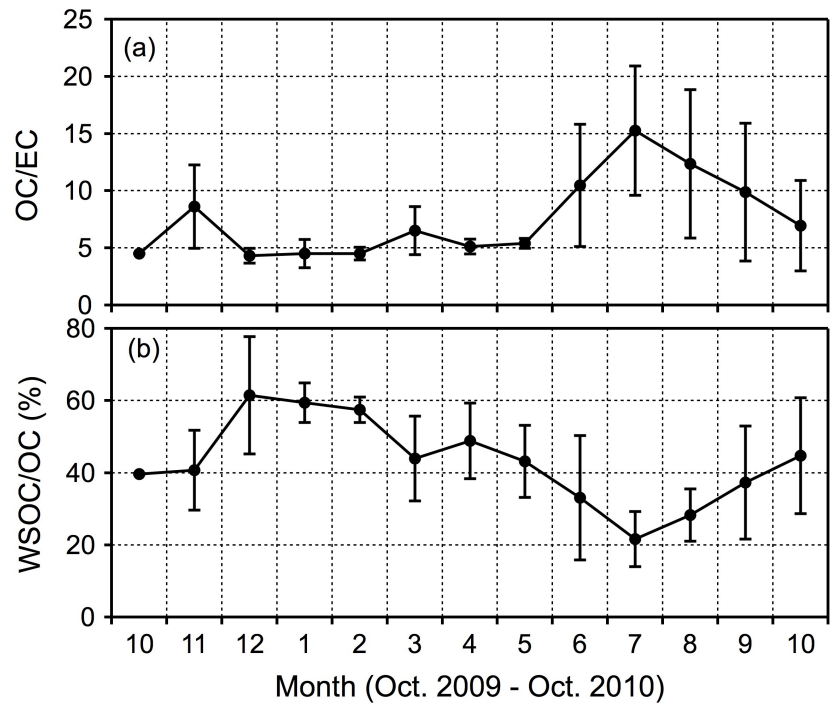

Fig. 7. Monthly average variations of concentration ratios of (a) organic carbon (OC) to elemental carbon (EC), and (b) water soluble organic carbon (WSOC) to organic carbon (OC) in ambient aerosols collected from Cape Hedo Okinawa during October 2009 to October 2010 . 
Table 2. Seasonal variations of ionic species in aerosols from Cape Hedo, Okinawa.

\begin{tabular}{|c|c|c|c|c|c|c|c|c|}
\hline \multicolumn{9}{|c|}{ Concentration $\left(\mu \mathrm{g} \mathrm{m}^{-3}\right)$} \\
\hline & \multicolumn{2}{|c|}{ Winter } & \multicolumn{2}{|c|}{ Spring } & \multicolumn{2}{|c|}{ Summer } & \multicolumn{2}{|c|}{ Autumn } \\
\hline Ions & Range & $\mathrm{AV} \pm \mathrm{SD}$ & Range & $\mathrm{AV} \pm \mathrm{SD}$ & Range & $\mathrm{AV} \pm \mathrm{SD}$ & Range & $\mathrm{AV} \pm \mathrm{SD}$ \\
\hline \multicolumn{9}{|c|}{ Anions } \\
\hline $\mathrm{F}^{-}$ & $0.00-0.01$ & $\mathrm{BDL} \pm \mathrm{BDL}$ & $0.00-0.01$ & $\mathrm{BDL} \pm \mathrm{BDL}$ & $0.00-0.01$ & $\mathrm{BDL} \pm \mathrm{BDL}$ & $0.00-0.01$ & $\mathrm{BDL} \pm \mathrm{BDL}$ \\
\hline $\mathrm{MSA}^{-}$ & $0.01-0.05$ & $0.03 \pm 0.01$ & $0.01-0.05$ & $0.04 \pm 0.02$ & $0.01-0.05$ & $0.02 \pm 0.01$ & $0.01-0.05$ & $0.02 \pm 0.02$ \\
\hline $\mathrm{Cl}^{-}$ & $4.63-26.2$ & $13.9 \pm 6.18$ & $4.63-26.2$ & $12.7 \pm 9.89$ & $3.31-12.1$ & $6.95 \pm 2.84$ & $2.84-26.2$ & $10.8 \pm 8.13$ \\
\hline $\mathrm{NO}_{2}^{-}$ & $0.00-0.00$ & $0.00 \pm 0.00$ & $0.00-0.00$ & $0.00 \pm 0.00$ & $0.00-0.00$ & $0.00 \pm 0.00$ & $0.00-0.00$ & $0.00 \pm 0.00$ \\
\hline $\mathrm{Br}^{-2}$ & $0.00-0.01$ & $0.00 \pm 0.00$ & $0.00-0.01$ & $0.00 \pm 0.00$ & $0.00-0.02$ & $0.01 \pm \mathrm{BDL}$ & $0.00-0.02$ & $0.01 \pm \mathrm{BDL}$ \\
\hline $\mathrm{NO}_{3}^{-}$ & $0.86-3.90$ & $2.11 \pm 0.93$ & $0.86-3.90$ & $1.95 \pm 1.42$ & $0.17-3.84$ & $0.79 \pm 0.97$ & $0.17-3.90$ & $1.81 \pm 1.35$ \\
\hline $\mathrm{PO}_{4}^{3-}$ & $0.00-0.00$ & $0.00 \pm 0.00$ & $0.00-0.01$ & $\mathrm{BDL} \pm \mathrm{BDL}$ & $0.00-0.01$ & $\mathrm{BDL} \pm \mathrm{BDL}$ & $0.00-0.01$ & $\mathrm{BDL} \pm \mathrm{BDL}$ \\
\hline $\mathrm{SO}_{4}^{2-}$ & $2.34-5.04$ & $3.63 \pm 0.82$ & $0.01-5.04$ & $2.37 \pm 2.04$ & $0.46-5.96$ & $1.29 \pm 1.47$ & $0.01-5.96$ & $2.54 \pm 1.96$ \\
\hline Total & $7.84-35.2$ & $19.7 \pm 7.94$ & $0.01-25.6$ & $8.32 \pm 7.15$ & $1.67-12.0$ & $4.14 \pm 2.89$ & $1.23-15.0$ & $6.90 \pm 4.08$ \\
\hline \multicolumn{9}{|c|}{ Cations } \\
\hline $\mathrm{Na}^{+}$ & $4.64-12.0$ & $7.57 \pm 2.40$ & $0.01-12.0$ & $5.34 \pm 4.68$ & $2.26-6.35$ & $3.58 \pm 1.30$ & $0.01-12.0$ & $5.19 \pm 3.85$ \\
\hline $\mathrm{NH}_{4}^{+}$ & $0.23-1.51$ & $0.79 \pm 0.41$ & $0.20-1.51$ & $0.74 \pm 0.48$ & $0.00-0.15$ & $0.02 \pm 0.05$ & $0.00-1.51$ & $0.51 \pm 0.53$ \\
\hline $\mathrm{K}^{+}$ & $0.20-0.68$ & $0.44 \pm 0.16$ & $0.01-0.68$ & $0.31 \pm 0.23$ & $0.12-0.43$ & $0.21 \pm 0.09$ & $0.01-0.68$ & $0.30 \pm 0.22$ \\
\hline $\mathrm{Ca}^{2+}$ & $0.30-1.35$ & $0.70 \pm 0.28$ & $0.00-1.35$ & $0.62 \pm 0.49$ & $0.09-0.37$ & $0.18 \pm 0.09$ & $0.00-1.35$ & $0.48 \pm 0.45$ \\
\hline $\mathrm{Mg}^{2+}$ & $0.48-1.48$ & $0.92 \pm 0.32$ & $0.00-1.48$ & $0.60 \pm 0.48$ & $0.24-0.66$ & $0.41 \pm 0.14$ & $0.00-1.48$ & $0.60 \pm 0.48$ \\
\hline Total & $5.85-17.0$ & $10.4 \pm 3.57$ & $10.3-44.7$ & $20.4 \pm 10.7$ & $6.26-18.2$ & $10.1 \pm 3.82$ & $3.72-35.8$ & $17.7 \pm 9.17$ \\
\hline
\end{tabular}

Note: BDL means Below Detection Limit $\left(0.001 \mu \mathrm{g} \mathrm{m}^{-3}\right)$.

combustion produces WSOC abundantly (Andreae et al., 1996). The higher WSOC/OC ratio in winter (Fig. 7b) suggests that significant fractions of organic aerosols were derived from biomass burning together with atmospheric oxidation of fossil fuel combustion products.

Kawamura et al. (2010) reported an increase of WSOC/TC ratios in the Arctic aerosols after polar sunrise due to extensive photochemical oxidation of organic precursors. The enhanced WSOC/OC ratios (av. $81 \%$ ) were also reported for summit Greenland aerosol (Hagler et al., 2007). We found highest WSOC/OC ratios in winter $(60 \%)$ followed by spring (45\%) and autumn (41\%). The lowest WSOC / OC ratio was observed in summer $(28 \%)$. The low ratio in summer may be caused by the sea-to-air emissions of waterinsoluble organic compounds that are produced by marine phytoplankton, because the summertime air masses are derived from the oceanic region (Fig. 2c). The average summertime WSOC/OC ratio from Cape Hedo aerosols $(28 \%)$ is slightly lower than that from Delhi aerosols (36\%). In summer, Delhi aerosols were also influenced by marine sources (Aggarwal et al., 2013). Miyazaki et al. (2010b) reported high abundance of WIOC in the western North Pacific during summer. The highest ratios in winter $(60 \%)$ may be due to the enhanced oxidation of primary organic compounds during long-range atmospheric transport and/or gas-to-particle conversion of anthropogenic semi-volatile polar compounds (Kawamura et al., 2010).
The previous studies of East Asian aerosols often showed wintertime maxima of OC. However, it is not the case in our samples from Cape Hedo. Table 3 compares the concentration of $\mathrm{OC}$ and $\mathrm{EC}$ together with $\mathrm{OC} / \mathrm{EC}$ ratios in East Asia. The annual average concentration of OC in Cape Hedo $\left(1.78 \mu \mathrm{g} \mathrm{m}^{-3}\right)$ is significantly less than those reported in Mongolia during winter (Jung et al., 2010), Chinese cities (Cao et al., 2007), Pearl Delta region, China (Cao et al., 2003), Kaohsiung, Taiwan (Lin and Tai, 2001) and Seoul, Korea (Park et al., 2002), and is also lower than that of Jeju Island (Lee et al., 2001) where Asian outflow is important. Based on these comparisons, we can insist that concentrations of OC decrease during long-range atmospheric transport via atmospheric dilution and/or dry and wet scavenging. The major sources of carbonaceous components include industrial and vehicular emissions, fossil fuel combustions and biomass burnings in East Asia (Wang et al., 2006).

\subsection{Seasonal variations of inorganic species}

The statistical summaries of water-soluble ionic species in the marine aerosol samples from Okinawa are given in Table 2. Their seasonal variations of cations and anions are shown in Fig. 8. The dominant cation in our samples was $\mathrm{Na}^{+}$followed by $\mathrm{Mg}^{2+}$ and $\mathrm{Ca}^{2+}$. The annual average concentrations of $\mathrm{Na}^{+}, \mathrm{Mg}^{2+}$ and $\mathrm{Ca}^{2+}$ are 5.78, 0.71 and $0.66 \mu \mathrm{g} \mathrm{m}^{-3}$, respectively, whose relative contributions to total aerosol mass are 9.3, 1.1 and $0.8 \%$, respectively. The 

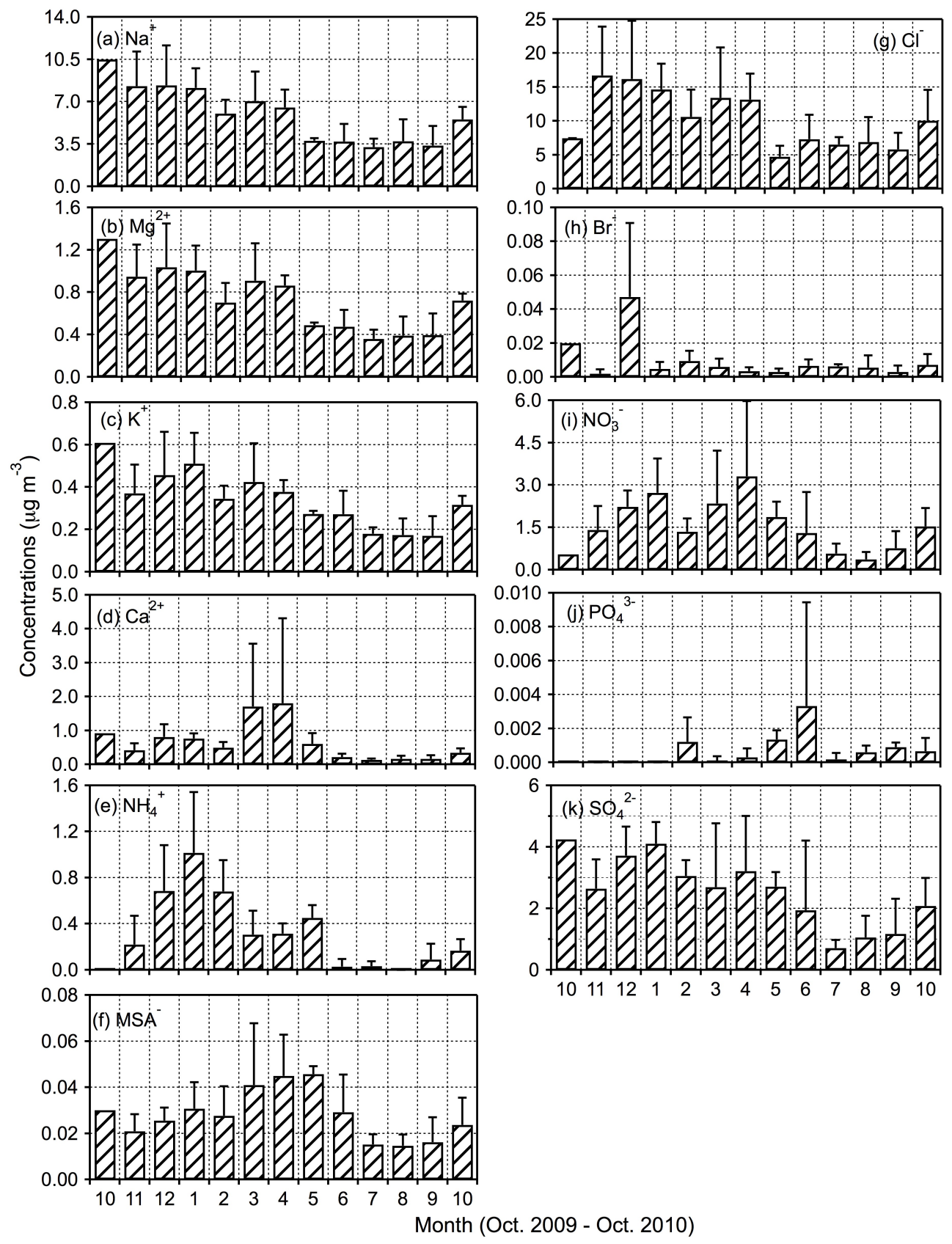

Fig. 8. Monthly average variations in concentrations of major ions (a) $\mathrm{Na}^{+}$, (b) $\mathrm{Mg}^{2+}$, (c) $\mathrm{K}^{+}$, (d) $\mathrm{Ca}^{2+}$, (e) $\mathrm{NH}_{4}^{+}$, (f) $\mathrm{MSA}^{-}$, (g) $\mathrm{Cl}^{-}$, (h) $\mathrm{Br}^{-}$, (i) $\mathrm{NO}_{3}^{-}$, (j) $\mathrm{PO}_{4}^{3-}$, and (k) $\mathrm{SO}_{4}^{2-}$ in the ambient aerosols collected from Cape Hedo, Okinawa.

dominant anion was $\mathrm{Cl}^{-}$followed by $\mathrm{SO}_{4}^{2-}$ and $\mathrm{NO}_{3}^{-}$. Their annual average concentrations are 10.8, 2.4 and $1.6 \mu \mathrm{g} \mathrm{m}^{-3}$, respectively, whose relative contributions to total aerosol mass were $17.1,3.7$ and $2.5 \%$, respectively. Similarly, the contributions of $\mathrm{Na}^{+}$and $\mathrm{Cl}^{-}$to total ions were on average $26.2 \%$ and $47 \%$, respectively. Average concentration of $\mathrm{Cl}^{-}$is 6 times higher than that of OC, suggesting that inorganic loading is very important throughout the year. $\mathrm{MSA}^{-}$, a tracer of marine biogenic sources, showed high concen- tration in spring, suggesting the emissions from biogenic marine sources. During the long-range atmospheric transport, East Asian aerosols travelled over the marine regions (the East China Sea, Sea of Japan and Pacific Ocean) and resided over the marine atmosphere for 1 to 2 days. During the travelling, the aerosol from East Asia is mixed with marine aerosols emitted from the ocean, which can be supported by individual backward trajectory. The summertime concentration of $\mathrm{MSA}^{-}$in Cape Hedo is comparable with 
Table 3. OC and EC concentrations and OC to EC mass ratios in atmospheric aerosols from different locations in East Asia.

\begin{tabular}{lllllll}
\hline Location & Period & Size & \multicolumn{2}{c}{ Concentrations $\left(\mu \mathrm{g} \mathrm{m}^{-3}\right)$} & OC /EC & References \\
& & & OC & EC & \\
\hline Mongolia & $11 / 2007$ to 01/2008 & $\mathrm{PM}_{2.5}$ & 31.8 & 6.7 & 4.7 & Jung et al. (2010) \\
Beijing & Winter & $\mathrm{PM}_{2.5}$ & 27.2 & 7.1 & 3.7 & Cao et al. (2007) \\
Beijing & Summer & $\mathrm{PM}_{2.5}$ & 17.2 & 4.6 & 4.4 & Cao et al. 2007) \\
Jinchang & Winter & $\mathrm{PM}_{2.5}$ & 23 & 5 & 4.5 & Cao et al. (2007) \\
Jinchang & Summer & $\mathrm{PM}_{2.5}$ & 8.1 & 1.6 & 5.9 & Cao et al. (2007) \\
Gangzhou & Winter & $\mathrm{PM}_{2.5}$ & 41.1 & 14.5 & 2.8 & Cao et al. (2007) \\
Gangzhou & Summer & $\mathrm{PM}_{2.5}$ & 10.6 & 3.2 & 3.6 & Cao et al. (2007) \\
Hong Kong & Winter & $\mathrm{PM}_{2.5}$ & 11.2 & 5.8 & 2 & Cao et al. (2007) \\
Hong Kong & Summer & $\mathrm{PM}_{10}$ & 7.3 & 3.6 & 2.1 & Cao et al. (2007) \\
Hong Kong, PU, China & Nov-Feb, 2000-2001 & $\mathrm{PM}_{2.5}$ & 12.0 & 6.86 & $>2$ & Ho et al. (2003) \\
Hong Kong, KT, China & Nov-Feb, 2000-2001 & $\mathrm{PM}_{2.5}$ & 10.1 & 5.05 & Ho et al. (2003) \\
Hong Kong, HT, China & Nov-Feb, 2000-2001 & $\mathrm{PM}_{2.5}$ & 5.52 & 1.36 & $>3$ & Ho et al. (2003) \\
PRD regions, China & $1-2 / 2002$ & $\mathrm{PM}_{2.5}$ & 14.7 & 6.1 & 2.4 & Cao et al. (2003) \\
Taiwan & $11 / 1998-04 / 1999$ & $\mathrm{PM}_{10}$ & 14.5 & 6.1 & 2.4 & Lin and Tai (2001) \\
Seoul, Korea & $11 / 27-12 / 09 / 1999$ & $\mathrm{PM}_{2.5}$ & 15.2 & 7.3 & 2.2 & Park et al. (2002) \\
Gosan (Jeju Island) & Dec 1996 & $\mathrm{PM}_{2.5}$ & 4.41 & 0.43 & 10 & Lee et al. (2001) \\
Gosan (Jeju Island) & Mar 1996 & $\mathrm{PM}_{2.5}$ & 2.97 & 0.32 & 9.3 & Lee et al. (2001) \\
Gosan (Jeju Island) & Jan-1997 & $\mathrm{PM}_{2.5}$ & 3.31 & 0.23 & 14 & Lee et al. (2001) \\
Gosan (Jeju Island) & Sep 1997 & $\mathrm{PM}_{2.5}$ & 3.56 & 0.42 & 8.5 & Lee et al. (2001) \\
Gosan (Jeju Island) & Dec, 1997 & $\mathrm{PM}_{2.5}$ & 2.6 & 0.34 & 7.7 & Lee et al. (2001) \\
Cape Hedo, Okinawa & Oct 2009 to Oct 2010 & $\mathrm{TSP}^{2}$ & 1.78 & 0.28 & This Study \\
\hline & & & & & 7.7 &
\end{tabular}

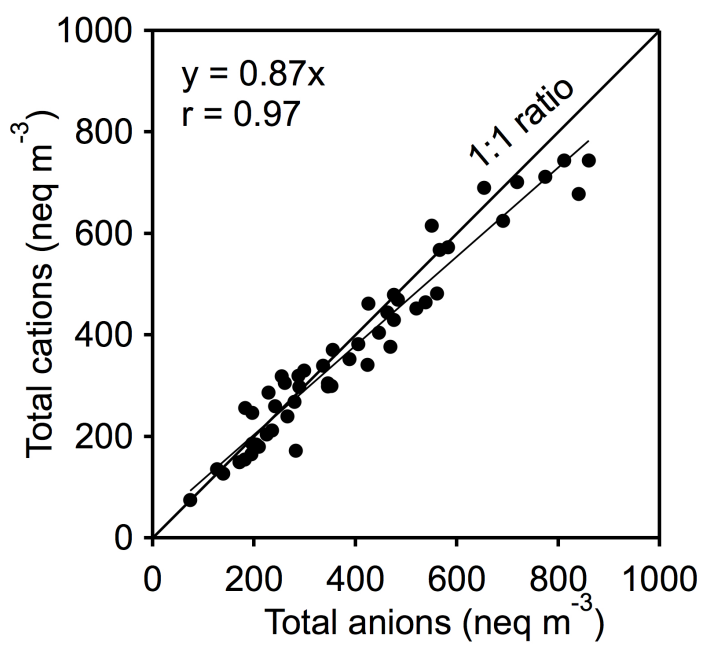

Fig. 9. Linear regression plots between sum of cation equivalents (neq) and anion equivalents (neq) in ambient aerosol samples collected from Cape Hedo, Okinawa during October 2009 to October 2010 .

those in the western North Pacific during summer (Miyazaki et al., 2010a). Similarly, nss- $\mathrm{K}^{+}$, a tracer of biomass burning, showed a good correlation with OC in winter (0.72) and spring $(0.65)$. The stronger correlation in winter suggests that biomass burning significantly contributes in winter than spring. Most cations and anions showed the highest concentrations in winter months and the lowest in summer (Fig. 8).

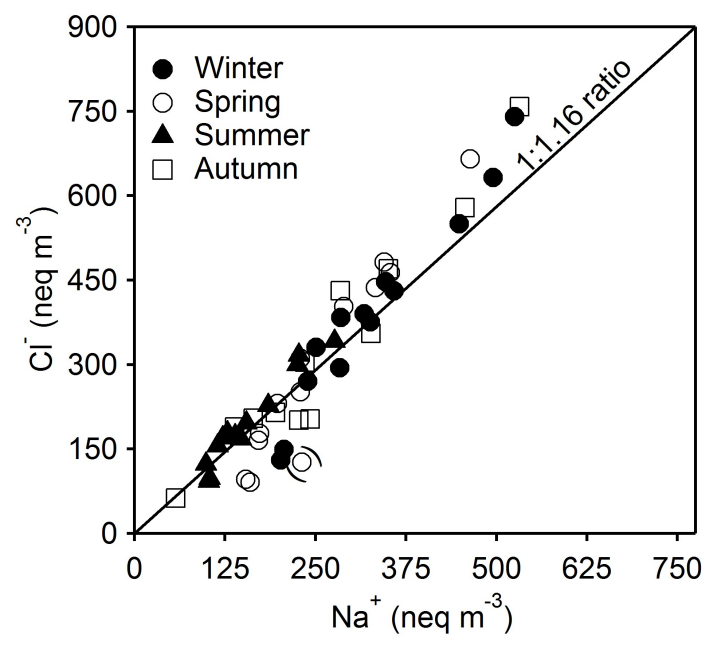

Fig. 10. Scatter plot showing variation of $\mathrm{Na}^{+}$and $\mathrm{Cl}^{-}$with respect to sea water line in ambient aerosols collected from Cape Hedo, Okinawa. The point within the bracket shows the maximum chlorine loss.

The relative abundances of $\mathrm{NO}_{3}^{-}, \mathrm{SO}_{4}^{2-}, \mathrm{NH}_{4}^{+}$in TSP showed a maximum in winter. These results suggest that contributions from fossil fuel combustion, industrial emission, and biomass burning are significant (Kundu et al., 2010) as well as animal excreta for $\mathrm{NH}_{3}$ (Pavuluri et al., 2011). In contrast, relative abundances of $\mathrm{Ca}^{2+}$ in TSP maximized in spring (Fig. 8d), suggesting a significant influence from 
crustal dust during spring. Concentrations of $\mathrm{Ca}^{2+}$ (a tracer of crustal material) also maximized in spring.

\subsubsection{Ion balance and correlations among major ions}

Ion balance calculation is used to evaluate the ion deficit between cations and anions in aerosols (Pavuluri et al., 2011). The following equations are used to derive the charge balance between cations and anions.

Cation equivalents $=\left[\mathrm{Na}^{+}\right] / 23+\left[\mathrm{NH}_{4}^{+}\right] / 18+\left[\mathrm{K}^{+}\right] / 39+$ $2 \times\left[\mathrm{Mg}^{2+}\right] / 24+2 \times\left[\mathrm{Ca}^{2+}\right] / 40$.

Anion equivalents $=2 \times\left[\mathrm{SO}_{4}^{2-}\right] / 96+\left[\mathrm{NO}_{3}^{-}\right] / 62.04+$ $\left[\mathrm{Cl}^{-}\right] / 35.5+\left[\mathrm{Br}^{-}\right] / 79.9+\left[\mathrm{MSA}^{-}\right] / 95.1+3 \times\left[\mathrm{PO}_{4}^{3-}\right] / 94.8$.

Average equivalent ratios of total cations $\left(\mathrm{Na}^{+}, \mathrm{NH}_{4}^{+}, \mathrm{K}^{+}\right.$, $\mathrm{Mg}^{2+}$, and $\left.\mathrm{Ca}^{2+}\right)$ to total anions $\left(\mathrm{SO}_{4}^{2-}, \mathrm{NO}_{3}^{-}, \mathrm{Cl}^{-}, \mathrm{Br}^{-}\right.$, $\mathrm{MSA}^{-}$and $\mathrm{PO}_{4}^{3-}$ ) were 0.96 with standard deviation of 0.14 $(n=50)$ as shown in Fig. 9. The slope (0.87) of less than 1 indicates that almost all of the ions had been quantified, although $\mathrm{CO}_{3}^{2-}, \mathrm{HCO}_{3}^{-}, \mathrm{H}^{+}$and organic anions were not determined.

Because the concentration of the ions emitted from the same source or similar reaction pathway should show a good correlation, correlation analyses among the ions would provide important information for their sources. Tables 4,5 , and 6 show the results of correlation analyses of major ions for winter, spring, and summer, respectively. Throughout the year, we found strong correlations among $\mathrm{Na}^{+}$, sea salt (ss)$\mathrm{K}^{+}$, ss- $\mathrm{Ca}^{2+}$, ss- $\mathrm{Mg}^{2+}$, $\mathrm{ss}_{-} \mathrm{SO}_{4}^{2-}$ and $\mathrm{Cl}^{-}$, indicating that these ions are derived from the sea spray.

In winter, $\mathrm{NO}_{3}^{-}$, a tracer of anthropogenic source, strongly correlates with $\mathrm{NH}_{4}^{+}$, nss- $\mathrm{K}^{+}$, and well correlates with nss$\mathrm{Mg}^{2+}$ (Table 4), suggesting that they are derived from anthropogenic sources in the Asian Continent. In spring, we did not find any significant correlation between $\mathrm{Na}^{+}$and $\mathrm{NO}_{3}^{-}$(Table 5). However, nss-Ca ${ }^{2+}$, a tracer of crustal dust, was found to well correlate with nss- $\mathrm{K}^{+}$and nss- $\mathrm{Mg}^{2+}$, indicating that they are derived from similar sources or reaction pathways. There is no correlation between $\mathrm{nss}_{-}-\mathrm{Ca}^{2+}$ and $\mathrm{Na}^{+}$in spring (Table 5). In summer, $\mathrm{NO}_{3}^{-}$showed a strong correlation with nss- $\mathrm{Mg}^{2+}$ and nss- $\mathrm{SO}_{4}^{2-}$ (Table 6), suggesting that they are formed from similar sources and/or reaction pathways. Both $\mathrm{NO}_{3}^{-}$and nss- $\mathrm{SO}_{4}^{2-}$ are produced by photochemical reactions in the atmosphere (Pavuluri et al., 2011). It should be noted that $\mathrm{ss}^{-\mathrm{SO}_{4}^{2-}}$ showed good correlations with $\mathrm{NH}_{4}^{+}$and $\mathrm{NO}_{3}^{-}$as well as other anthropogenic tracers (nss- $\mathrm{K}^{+}$, nss- $\mathrm{Mg}^{2+}$ ) during winter and spring (Tables 4 and 5). $\mathrm{NH}_{3}$ and $\mathrm{HNO}_{3}$ probably react with sea salt in the marine atmosphere.

\subsubsection{Sea salt and non-sea salt ions}

Sea salt is the major component in the marine and coastal aerosols (George et al., 2008; Prospero, 2002). $\mathrm{Na}^{+}$is used as a tracer to evaluate the contributions of sea salt to aerosols.
The equivalent ratio of $\mathrm{Cl}^{-}$to $\mathrm{Na}^{+}$is 1.16 in seawater. We estimated equivalent ratios of $\mathrm{Cl}^{-} / \mathrm{Na}^{+}$in each samples and compared with seawater. Figure 10 presents scatter plots of $\mathrm{Na}^{+}$and $\mathrm{Cl}^{-}$concentration for different seasons. Throughout the year, only few data points are found to locate below the sea water line, indicating that the loss of $\mathrm{Cl}$ was insignificant except for spring samples. Chlorine loss has been observed in many coastal regions and open oceans (Meinert and Winchester, 1977; George et al., 2008; Yao and Zhang, 2012). In some spring samples, estimated chlorine loss was up to $50 \%$, indicating that vigorous reaction occurs between gaseous $\mathrm{HNO}_{3}$ and $\mathrm{H}_{2} \mathrm{SO}_{4}$, and $\mathrm{NaCl}$ to emit gaseous $\mathrm{HCl}$ (McInnes et al., 1994) in spring.

Ions such as $\mathrm{SO}_{4}^{2-}, \mathrm{K}^{+}, \mathrm{Ca}^{2+}$, and $\mathrm{Mg}^{2+}$ have multiple sources, i.e. oceanic and continental. Additionally, $\mathrm{SO}_{4}^{2-}$ has another oceanic, but nss-source generated by the oxidation of dimethyl sulphide (DMS) that is emitted from the phytoplankton in the sea surface (George et al., 2008; Savoie et al., 1994). Figure 11 shows the monthly variation of ss- and nssspecies. ss- $\mathrm{Mg}^{2+}$ and $\mathrm{K}^{+}$dominate over the nss forms. Interestingly, nss-Ca ${ }^{2+}$ dominated over the ss-Ca ${ }^{2+}$ until May with maxima in March and April while after June it was replaced by the ss-Ca ${ }^{2+}$ (Fig. 11b). Major fraction of $\mathrm{Ca}^{2+}$ should be derived from Asian dusts in winter and spring (Kawamura et al., 2004). The percentage of nss- $\mathrm{Ca}^{2+}$ to total $\mathrm{Ca}^{2+}$ was found highest in winter (62\%) to spring (71.5\%) and decreases towards summer $(31.1 \%)$. In spring, the air masses uplift the crustal dust in East Asia and transport over the sampling site. We found strong correlation between nss$\mathrm{Ca}^{2+}$ and TSP $(r=0.81)$ in spring, suggesting that crustal dust from East Asia is the main source of TSP. Similar strong correlation was found between nss-Ca ${ }^{2+}$ and TSP in Gosan site, Jeju Island (Kawamura et al., 2004). However, for the rest of the year, we did not find any good correlation between nss- $\mathrm{Ca}^{2+}$ and TSP.

Similarly, the contribution of nss- $\mathrm{K}^{+}$to total $\mathrm{K}^{+}$was found highest in winter $(40.6 \%)$ to spring $(46.2 \%)$ with a decrease toward summer $(37.1 \%) . \mathrm{K}^{+}$is a tracer of biomass burning (Kundu et al., 2010) whereas EC is a tracer of incomplete combustions of fossil fuel and biomass burning. We found a strong relation between nss- $\mathrm{K}^{+}$and EC $(r=0.80)$ (Fig. 12), indicating that the major fraction of EC is formed by biomass burning. The contribution of nss- $\mathrm{Mg}^{2+}$ to total $\mathrm{Mg}^{2+}$ increased in winter (30.9\%) to spring $(35.8 \%)$ and decreased in summer (27.4\%). Because $\mathrm{Mg}$ is also found in the crustal dust (Wang et al., 2010), this study again indicates that our sampling site is strongly influenced by Asian dust in spring. Although all the air masses come from the ocean in summer, the loading of sea salt components maximized in winter and spring and became lowest in summer. In winter and spring when westerlies became strong, continental air masses that stayed over the ocean for few days were mixed with marine aerosols according to the backward trajectory analysis. 
Table 4. Correlation coefficients $(r)$ of major ions in winter aerosols from Cape Hedo, Okinawa.

\begin{tabular}{|c|c|c|c|c|c|c|c|c|c|c|c|c|}
\hline & $\mathrm{Na}^{+}$ & $\mathrm{NH}_{4}^{+}$ & $\mathrm{nss} \mathrm{K}^{+}$ & ss $^{+}$ & $\mathrm{nssCa}^{2+}$ & $\mathrm{ssCa}^{2+}$ & $\mathrm{nssMg}^{2+}$ & $\mathrm{ssMg}^{2+}$ & $\mathrm{Cl}^{-}$ & $\mathrm{NO}_{3}^{-}$ & $\mathrm{nssSO}_{4}^{2-}$ & $\mathrm{ssSO}_{4}^{2-}$ \\
\hline $\mathrm{Na}^{+}$ & 1 & & & & & & & & & & & \\
\hline $\mathrm{NH}_{4}^{+}$ & 0.54 & 1 & & & & & & & & & & \\
\hline $\mathrm{nssK}^{+}$ & 0.63 & 0.94 & 1 & & & & & & & & & \\
\hline $\operatorname{ssK}^{+}$ & 1.00 & 0.54 & 0.63 & 1 & & & & & & & & \\
\hline $\mathrm{nssCa}^{2+}$ & 0.16 & 0.26 & 0.30 & 0.16 & 1 & & & & & & & \\
\hline $\mathrm{ssCa}^{2+}$ & 1.00 & 0.54 & 0.63 & 1.00 & 0.16 & 1 & & & & & & \\
\hline $\mathrm{nssMg}^{2+}$ & 0.92 & 0.64 & 0.73 & 0.92 & 0.37 & 0.92 & 1 & & & & & \\
\hline $\mathrm{ssMg}^{2+}$ & 1.00 & 0.54 & 0.63 & 1.00 & 0.16 & 1.00 & 0.92 & & & & & \\
\hline $\mathrm{Cl}^{-}$ & 0.97 & 0.44 & 0.55 & 0.97 & 0.22 & 0.97 & 0.91 & 0.97 & 1 & & & \\
\hline $\mathrm{NO}_{3}^{-}$ & 0.48 & 0.85 & 0.83 & 0.48 & 0.42 & 0.48 & 0.62 & 0.49 & 0.35 & 1 & & \\
\hline $\mathrm{nssSO}_{4}^{2-}$ & -0.48 & 0.02 & -0.05 & -0.48 & -0.34 & -0.49 & $-0.54)$ & -0.49 & -0.62 & 0.11 & 1 & \\
\hline $\mathrm{ssSO}_{4}^{2-}$ & 0.86 & 0.80 & 0.80 & 0.86 & 0.35 & 0.86 & 0.87 & 0.86 & 0.76 & 0.77 & -0.30 & 1 \\
\hline
\end{tabular}

$t$ test is $<0.01$ for the correction where $r$ is $\geq 0.71$

$t$ test is $<0.05$ for the correction where $r$ is $\geq 0.54$ to 0.70

Table 5. Correlation coefficients $(r)$ of major ions in spring aerosols from Cape Hedo, Okinawa.

\begin{tabular}{|c|c|c|c|c|c|c|c|c|c|c|c|c|}
\hline & $\mathrm{Na}^{+}$ & $\mathrm{NH}_{4}^{+}$ & $\mathrm{nss} \mathrm{K}^{+}$ & $\operatorname{ss~K}^{+}$ & $\mathrm{nssCa}^{2+}$ & $\mathrm{ssCa}^{2+}$ & $\mathrm{nssMg}^{2+}$ & $\mathrm{ssMg}^{2+}$ & $\mathrm{Cl}^{-}$ & $\mathrm{NO}_{3}^{-}$ & $\mathrm{nssSO}_{4}^{2-}$ & $\mathrm{ssSO}_{4}^{2-}$ \\
\hline $\mathrm{Na}^{+}$ & 1 & & & & & & & & & & & \\
\hline $\mathrm{NH}_{4}^{+}$ & -0.35 & 1 & & & & & & & & & & \\
\hline $\mathrm{nssK}^{+}$ & 0.53 & -0.16 & 1 & & & & & & & & & \\
\hline $\mathrm{ssK}^{+}$ & 1.00 & -0.35 & 0.53 & 1 & & & & & & & & \\
\hline $\mathrm{nssCa}^{2+}$ & 0.28 & -0.38 & 0.76 & 0.28 & 1 & & & & & & & \\
\hline $\mathrm{ssCa}^{2+}$ & 1.00 & -0.35 & 0.53 & 1.00 & 0.28 & 1 & & & & & & \\
\hline $\mathrm{nssMg}^{2+}$ & 0.65 & -0.26 & 0.87 & 0.65 & 0.79 & 0.65 & & & & & & \\
\hline $\operatorname{ssMg}^{2+}$ & 1.00 & -0.35 & 0.53 & 1.00 & 0.28 & 1.00 & 0.65 & 1 & & & & \\
\hline $\mathrm{Cl}^{-}$ & 0.91 & -0.24 & 0.57 & 0.91 & 0.35 & 0.91 & 0.63 & 0.91 & 1 & & & \\
\hline $\mathrm{NO}_{3}^{-}$ & 0.47 & -0.47 & 0.43 & 0.48 & 0.22 & 0.48 & 0.27 & 0.48 & 0.51 & 1 & & \\
\hline $\mathrm{nssSO}_{4}^{2-}$ & -0.33 & -0.05 & 0.40 & -0.33 & 0.70 & -0.33 & 0.36 & -0.33 & -0.18 & -0.26 & 1 & \\
\hline $\mathrm{ssSO}_{4}^{2-}$ & 0.70 & -0.14 & 0.85 & 0.70 & 0.53 & 0.70 & 0.71 & 0.70 & 0.81 & 0.69 & 0.05 & 1 \\
\hline
\end{tabular}

$t$ test is $<0.01$ for the correction where $r$ is $\geq 0.71$

$t$ test is $<0.05$ for the correction where $r$ is $\geq 0.54$ to 0.70 .

\subsubsection{Anthropogenic aerosols and ionic composition}

nss- $\mathrm{SO}_{4}^{2-}$ in the atmosphere is derived from many sources. It can originate from mineral dusts from the desert/arid region, and combustion of fossil fuels. We found the highest concentration of nss-SO ${ }_{4}^{2-}$ in winter (av. $1.74 \mu \mathrm{g} \mathrm{m}^{-3}$ ) fol-

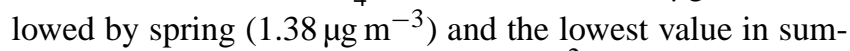
mer $\left(0.51 \mu \mathrm{g} \mathrm{m}^{-3}\right)$. The higher nss- $\mathrm{SO}_{4}^{2-}$ concentration in winter and spring suggest that the air quality of Cape Hedo is strongly influenced by fossil fuel combustions and industrial emissions in East Asia via a long-range atmospheric transport. However, we also suspect a possible contribution of shipping emissions of nss- $\mathrm{SO}_{4}^{2-}$ in the East China Sea to the Cape Hedo site during winter and spring. $\mathrm{NO}_{3}^{-}$is a tracer of anthropogenic activities and is derived from coal combustions, biomass burning and vehicular emissions (Kundu et al., 2010). We found a positive correlation between $\mathrm{NO}_{3}^{-}$and biomass burning tracer (nss- $\left.\mathrm{K}^{+}\right)(r=0.65)$ in winter, suggesting that $\mathrm{NO}_{3}^{-}$is associated with biomass burning.

To better understand the sources of nitrogenous components, we calculated $\mathrm{NH}_{4}-\mathrm{N} / \mathrm{WSTN}$ and $\mathrm{NO}_{3}-\mathrm{N} / \mathrm{WSTN}$ ratios. We found that $\mathrm{NH}_{4}-\mathrm{N} / \mathrm{WSTN}$ ratios maximized in winter $(0.56)$ followed by spring $(0.42)$, suggesting that biomass burning is important sources of WSTN in winter. Similarly, $\mathrm{NO}_{3}$-N/WSTN showed higher ratios in spring (0.51) followed by winter $(0.44)$ and autumn $(0.18)$. Lowest values of $\mathrm{NH}_{4}-\mathrm{N} / \mathrm{WSTN}(0.07)$ and $\mathrm{NO}_{3}-\mathrm{N} / \mathrm{WSTN}(0.11)$ were obtained in summer due to less chance for the continental outflow of polluted air masses.

\subsubsection{Neutralization factor and ionic composition}

The acid neutralization capacity of desired cation is estimated by neutralization factor $(\mathrm{NF}) . \mathrm{NO}_{3}^{-}$and $\mathrm{SO}_{4}^{2-}$, which are formed by secondary oxidation of $\mathrm{NO}, \mathrm{NO}_{2}$ and $\mathrm{SO}_{2}$, are major acid-producing anions, whereas $\mathrm{Ca}^{2+}, \mathrm{Mg}^{2+}, \mathrm{NH}_{4}^{+}$ 
Table 6. Correlation coefficients $(r)$ of major ions in summer aerosols from Cape Hedo, Okinawa.

\begin{tabular}{|c|c|c|c|c|c|c|c|c|c|c|c|c|}
\hline & $\mathrm{Na}^{+}$ & $\mathrm{NH}_{4}^{+}$ & $\mathrm{nss} \mathrm{K}^{+}$ & $\mathrm{ss} \mathrm{K}^{+}$ & $\mathrm{nssCa}^{2+}$ & $\mathrm{ssCa}^{2+}$ & $\mathrm{nssMg}^{2+}$ & $\mathrm{ssMg}^{2+}$ & $\mathrm{Cl}^{-}$ & $\mathrm{NO}_{3}^{-}$ & $\mathrm{nssSO}_{4}^{2-}$ & $\mathrm{ssSO}_{4}^{2-}$ \\
\hline $\mathrm{Na}^{+}$ & 1 & & & & & & & & & & & \\
\hline $\mathrm{NH}_{4}^{+}$ & 0.23 & 1 & & & & & & & & & & \\
\hline $\mathrm{nssK}^{+}$ & -0.09 & 0.02 & 1 & & & & & & & & & \\
\hline $\mathrm{ssK}^{+}$ & 1.00 & 0.23 & -0.09 & & & & & & & & & \\
\hline $\mathrm{nssCa}^{2+}$ & -0.03 & -0.07 & 0.90 & -0.03 & 1 & & & & & & & \\
\hline $\mathrm{ssCa}^{2+}$ & 1.00 & 0.23 & -0.09 & 1.00 & -0.04 & 1 & & & & & & \\
\hline $\mathrm{nssMg}^{2+}$ & 0.29 & -0.06 & 0.86 & 0.29 & 0.79 & 0.291 & & & & & & \\
\hline $\mathrm{ssMg}^{2+}$ & 1.00 & 0.23 & -0.09 & 1.00 & -0.04 & 1.000 .29 & 1 & & & & & \\
\hline $\mathrm{Cl}^{-}$ & 0.97 & 0.27 & -0.17 & 0.97 & -0.18 & 0.97 & 0.23 & 0.97 & 1 & & & \\
\hline $\mathrm{NO}_{3}^{-}$ & -0.20 & 0.07 & 0.93 & -0.20 & 0.93 & -0.21 & 0.77 & -0.21 & -0.32 & 1 & & \\
\hline $\mathrm{nssSO}_{4}^{2-}$ & -0.28 & -0.14 & 0.94 & -0.28 & 0.93 & -0.28 & 0.73 & -0.28 & -0.39 & 0.94 & 1 & \\
\hline $\mathrm{ssSO}_{4}^{2-}$ & 0.79 & 0.05 & 0.32 & 0.79 & 0.47 & 0.79 & 0.56 & 0.79 & 0.65 & 0.27 & 0.23 & 1 \\
\hline
\end{tabular}

$t$ test is $<0.01$ for the correction where $r$ is $\geq 0.71$

$t$ test is $<0.05$ for the correction where $r$ is $\geq 0.54$ to 0.70 .

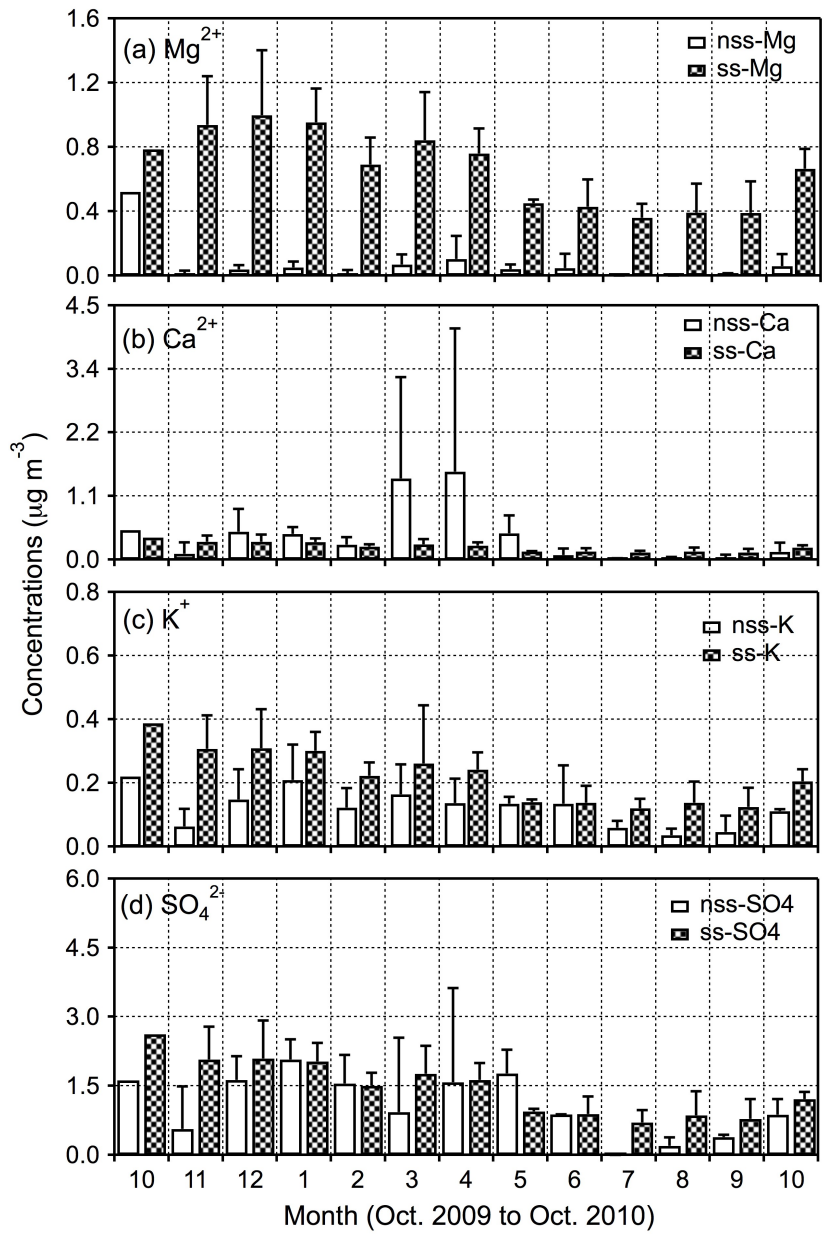

Fig. 11. Estimated mass concentration of sea salt (ss) and non-sea salt (nss) component of (a) $\mathrm{Mg}^{2+}$, (b) $\mathrm{Ca}^{2+}$, (c) $\mathrm{K}^{+}$, and (d) $\mathrm{SO}_{4}^{2-}$ in ambient aerosols collected from Cape Hedo, Okinawa.

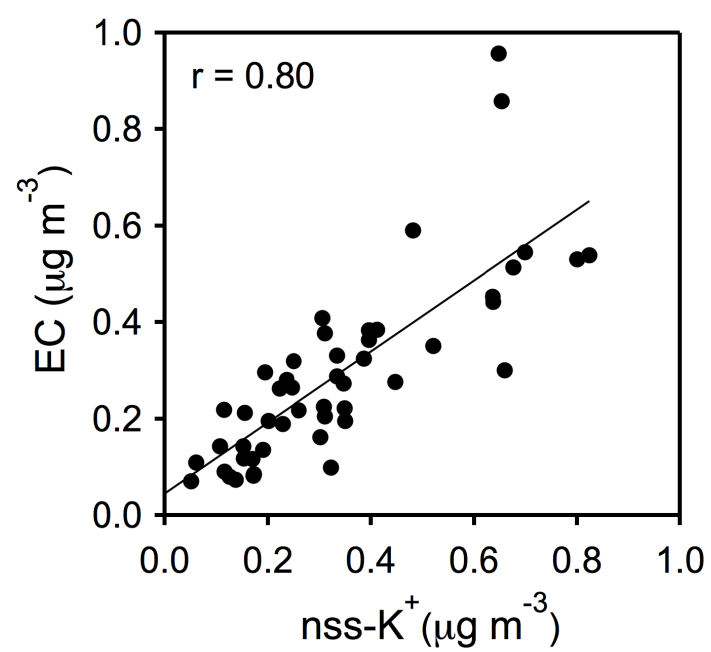

Fig. 12. Correlation analysis between nss-K and EC in ambient aerosols collected from Cape Hedo, Okinawa.

and $\mathrm{K}^{+}$are the cations that neutralize acids. The role of $\mathrm{Cl}^{-}$ in acid production is negligible because $\mathrm{Cl}^{-}$mainly comes from the ocean as sea salt. We calculated NF and using following formula (Keene et al., 1986).

$$
\begin{aligned}
& \mathrm{NF}\left(\mathrm{Ca}^{2+}\right)=\left[\mathrm{nss}-\mathrm{Ca}^{2+}\right] /\left(\left[\mathrm{NO}_{3}^{-}\right]+\left[\mathrm{nss}-\mathrm{SO}_{4}^{2-}\right]\right) \\
& \mathrm{NF}\left(\mathrm{Mg}^{2+}\right)=\left[\mathrm{nss}-\mathrm{Mg}^{2+}\right] /\left(\left[\mathrm{NO}_{3}^{-}\right]+\left[\mathrm{nss}-\mathrm{SO}_{4}^{2-}\right]\right) \\
& \mathrm{NF}\left(\mathrm{K}^{+}\right)=\left[\mathrm{nss}-\mathrm{K}^{+}\right] /\left(\left[\mathrm{NO}_{3}^{-}\right]+\left[\mathrm{nss}-\mathrm{SO}_{4}^{2-}\right]\right) \\
& \mathrm{NF}\left(\mathrm{NH}_{4}^{+}\right)=\left[\mathrm{NH}_{4}^{+}\right] /\left(\left[\mathrm{NO}_{3}^{-}\right]+\left[\mathrm{nss}-\mathrm{SO}_{4}^{2-}\right]\right)
\end{aligned}
$$

We found that $\mathrm{NH}_{4}^{+}$plays a major role in the neutralization of acidic species. The order of $\mathrm{NF}$ is $\mathrm{NH}_{4}^{+}>\mathrm{Ca}^{2+}>\mathrm{K}^{+}>\mathrm{Mg}^{2+}$. The NF of $\mathrm{NH}_{4}^{+}$and $\mathrm{Ca}^{2+}$ were found highest in winter followed by spring, suggesting that all the acidic species were neutralized with $\mathrm{CaCO}_{3}, \mathrm{MgCO}_{3}$ and $\mathrm{NH}_{4}^{+} \cdot \mathrm{Ca}^{2+}$ and 
$\mathrm{SO}_{4}^{2-}$ show positive correlation $(r=0.77)$, suggesting that these ions mainly exist as $\mathrm{CaSO}_{4}$. The mean $\mathrm{Ca}^{2+}$ to $\mathrm{SO}_{4}^{2-}$ mass ratio in our samples is 0.53 , being similar to the ionic mass ratio of 0.41 in $\mathrm{CaSO}_{4} . \mathrm{NH}_{4}^{+}$and $\mathrm{SO}_{4}^{2-}$ showed a good correlation $(r=0.87)$ with the mean $\mathrm{NH}_{4}^{+}$to $\mathrm{SO}_{4}^{2-}$ ratio of 0.2 , which lies in between the $\mathrm{NH}_{4}^{+}$to $\mathrm{SO}_{4}^{2-}$ mass ratios (0.37) and $\mathrm{NH}_{4}^{+}$to $\mathrm{HSO}_{4}^{-}$mass ratio (0.18). This result indicates that $\mathrm{NH}_{4}^{+}$and $\mathrm{SO}_{4}^{2-}$ exist in the form of $\left(\mathrm{NH}_{4}\right)_{2} \mathrm{SO}_{4}$ or $\mathrm{NH}_{4} \mathrm{HSO}_{4}$ and/or the combination of the two forms. Among these forms, the dominant composition may be $\mathrm{NH}_{4} \mathrm{HSO}_{4}$ because the measured mass ratios (0.2) is closer to the mass ratio of $\mathrm{NH}_{4} \mathrm{HSO}_{4}$ rather than that of $\left(\mathrm{NH}_{4}\right)_{2} \mathrm{SO}_{4}$.

\section{Summary and conclusions}

We conducted one-year observation of chemical compositions in aerosol (TSP) samples collected in Okinawa Island, which is located in an outflow region of Asian dusts. The highest aerosol mass loading and highest concentration of nss- $\mathrm{Ca}^{2+}$ in spring are caused by strong westerly winds, which uplift the mineral particles from the arid regions in China and Mongolia and then transport over the Pacific.

In contrast to East Asia (wintertime maximum), we found higher concentration of $\mathrm{OC}$ in spring (av. $2.36 \mu \mathrm{g} \mathrm{m}^{-3}$ ) than winter (av. $1.53 \mu \mathrm{g} \mathrm{m}^{-3}$ ). Higher concentration of OC was obtained during active biota seasons; spring and summer $\left(1.79 \mu \mathrm{g} \mathrm{m}^{-3}\right)$. We also determined WSTN and WSON. Higher concentrations of WSTN were found in winter and higher WSON concentrations were found in summer, suggesting more emissions of water-soluble organic nitrogen from the ocean.

Springtime maxima of OC / EC ratios, $\mathrm{MSA}^{-}$and correlation coefficients of $\mathrm{OC}$ and $\mathrm{EC}(\mathrm{r}=0.81)$, and $\mathrm{MSA}^{-}(0.81)$ showed an importance of terrestrial and marine biogenic sources as well as anthropogenic sources in spring although the contribution from biogenic source is less significant. Similarly, moderate positive correlation between OC and nss- $\mathrm{K}^{+}$ was found in both winter $(r=0.72)$ and spring $(0.65)$, suggesting that biomass burning contribution is higher in winter season followed by spring. We found an extremely higher $\mathrm{OC} / \mathrm{EC}$ ratio and strong correlation between $\mathrm{OC}$ and $\mathrm{MSA}^{-}$ $(0.71)$ in summer, further suggesting a strong biogenic emission of OC coupled with photochemical formation of SOC in hot season. The highest SOC concentration in July suggests the oxidation of organic compounds under strong solar radiation. Very high WSOC / OC ratios $(0.6)$ found in winter suggest an important contribution of biomass burning products from the Asian Continent as well as the active oxidation of anthropogenic primary organic compounds emitted from East Asian countries even in cold season during longrange atmospheric transport, followed by the subsequent gasto-particle conversion.
The high concentrations of $\mathrm{NO}_{3}^{-}$and $\mathrm{SO}_{4}^{2-}$, and enhanced $\mathrm{NH}_{4}$-N/WSTN ratio in winter suggest that Cape Hedo is strongly influenced by vehicular emission, biomass burning, industrial emission and coal combustion in East Asia via a long-range atmospheric transport. We found a strong correlation between the biomass burning tracer (nss- $\mathrm{K}^{-}$) and EC $(r=0.80)$, suggesting an important contribution of incomplete combustion of biomass to EC in the Asian outflow region.

Acknowledgements. This study was in part supported by the Japan Society for the Promotion of Science (Grant-in-Aid Nos. 1920405 and 24221001) and by the Environment Research and Technology Development Fund (B-0903) from the Ministry of the Environment, Japan. We thank S. Yamamoto and T. Arakaki for the help in aerosol sampling at Cape Hedo, Okinawa, Japan, and A. Takami of the National Institute of Environmental Studies, Japan for the courtesy to use the CHAARM site at Cape Hedo. We also thank the NOAA Air Resources Laboratory (ARL) for the provision of the HYSPLIT transport model and READY website (http://www.arl.noaa.gov/ready.php) used in this publication.

Edited by: N. Mihalopoulos

\section{References}

Aggarwal, S. G. and Kawamura, K.: Molecular distributions and stable carbon isotopic compositions of dicarboxylic acids and related compounds in aerosols from Sapporo, Japan: Implications for photochemical aging during longrange atmospheric transport, J. Geophys. Res., 113, D14301, doi:10.1029/2007JD009365, 2008.

Aggarwal S. G., Kawamura, K., Umarji, G. S., Tachibana, E., Patil, R. S., and Gupta, P. K.: Organic and inorganic markers and stable $\mathrm{C}$-, $\mathrm{N}$-isotopic compositions of tropical coastal aerosols from megacity Mumbai: Sources of organic aerosols and atmospheric processing, Atmos. Chem. Phys., 13, 4667-4680, 2013, http://www.atmos-chem-phys.net/13/4667/2013/.

Andreae, M. O. and Merlet, P.: Emission of trace gases and aerosols from biomass burning, Global Biogeochem. Cy., 15, 955-966, 2001.

Andreae, M. O., Atlas, E., Cachier, H., Cofer III, W. R., Harris, G. W., Helas, G., Koppmann, R., Lacaux, J. P., and Ward, D. E.: Trace gas and aerosol emissions from savanna fires, in Biomass Burning and Global Change, edited by: Levine, J. S., 278-295, MIT Press, Cambridge, Mass., 1996.

Arakaki, T., Okada, Y. K., Nakama, Y., Ikota, H., Kinjo, M., Higuchi, T., Uehara, M., and Tanahara, A.: Chemical composition and photochemical formation of hydroxyl radicals in aqueous extracts of aerosol particles collected in Okinawa, Japan, Atmos. Environ., 40, 4764-4774, doi:10.1016/j.atmosenv.2006.04.035, 2006.

Berg Jr., W. W. and Winchester, J. W.: Aerosol chemistry of marine atmosphere, in Chemical Oceanography., vol. 7, edited by: Riley, J. P. and Chester, R., 173-231, Academic Press, London, UK, 1978. 
Cao, J. J., Lee, S. C., Ho, K. F., Zhang, X. Y., Zou, S. C., Fung, K., Chow, J. C., and Watson, J. G.: Characteristic of carbonaceous aerosol on Pearl River Delta region, China during 2001 winter period, Atmos. Environ. 37, 1451-1460, 2003.

Cao, J. J., Lee, S. C., Zhang, X. Y., Chow, J. C., An, Z. S., Ho, K. F., Watson, J. G., Fung, K., Wang, Y. Q., and Shen, Z. X.: Characterization of airborne carbonate over a site on Asian Dust source regions during 2002 spring and its climatic and environmental significance, J. Geophys. Res., 110, D03203, doi:10.1029/2004JD005244, 2005.

Cao, J. J., Lee, S. C., Chow, J. C., Watson, J. G., Ho, K. F., Zhang, R. J., Jin, Z. D., Shen, Z. X., Chen, G. C., Kang, Y. M., Zou, S. C., Zhang, L. Z., Qi, S. H., Dai, M. H., Cheng, Y., and Hu, K.: Spatial and seasonal distributions of carbonaceous aerosols over China, J. Geophys. Res., 112, D22S11, doi:10.1029/2006JD008205, 2007.

Cape, J. N., Cornell, S. E., Jickells, T. D., and Nemitz, E.: Organic nitrogen in the atmosphere-Where does it come from? A review of sources and methods, Atmos. Res., 102, 30-48, 2011.

Castro, L. M., Pio, C. A., Harrison, R. M., and Smith, D. J. T.: Carbonaceous aerosol in urban and rural European atmosphere: estimation of secondary organic carbon concentrations, Atmos. Environ., 33, 2771-2781, 1999.

Cooke, W. F., Liousse, C., Cachier, H., and Feichter, J.: Construction of a $1^{\circ} \mathrm{x} 1^{\circ}$ fossil fuel emission data set for carbonaceous aerosol and implementation and radiative impact in the ECHAM4 model, J. Geophys. Res., 104, 22137-22162, 1999.

Draxler, R. R. and Rolph, G. D.: HYSPLIT (HYbrid Single-Particle Lagrangian Integrated Trajectory) Model Access via NOAA ARL READY Website, available at: http://www.arl.noaa.gov/ ready/hysplit4.html, (last access: August 2011), NOAA Air Resources Laboratory, Silver Spring, MD, 2003.

Folinsbee, L. J.: Human Health Effects of Air Pollution, Environ. Health Perspect., 100, 45-56, 1992.

George, K. S., Nair, P. R., Parameswaran, K., Jacob, S., and Abraham, A.: Seasonal trend in chemical composition of aerosols at a tropical coastal site of India, J. Geophys. Res., 113, D16209, doi:10.1029/2007JD009507, 2008.

Hagler, G. S. W., Bergin, M. H., Smith, E. A., and Dibb, J. E.: A summer time series of particulate carbon in the air and snow at Summit, Greenland, J. Geophys. Res., 112, D21309, doi:10.1029/2007JD008993, 2007.

Handa, D., Nakajima, H., Arakaki, T., Kumata, H., Shibata, Y., and Uchida, M.: Radiocarbon analysis of $\mathrm{BC}$ and $\mathrm{OC}$ in $\mathrm{PM}_{10}$ aerosols at Cape Hedo, Okinawa, Japan, during long-range transport events from East Asian countries, Nucl. Instrum. Meth., B, 268, 1125-1128, 2010.

Ho, K. F., Cao, J. J., Lee, S. C., Kawamura, K., Zhang, R. J., Chow, J. C., and Watson, J. G.: Dicarboxylic acids, ketocarboxylic acids and dicarbonyls in the urban atmosphere of China, J. Geophys. Res., 112, D22S27, doi:10.1029/2006JD008011, 2007.

Jaffe, D., Prestbo, E., Swartzendruber, P., Penzias, P. W., Kato, S., Takami, A., Hatakeyama, S., and Kajii, Y.: Export of atmospheric mercury from Asia, Atmos. Environ., 39, 3029-3038, 2005.

Jung, J., Tsatsral, B., Kim, Y. J., and Kawamura, K.: Organic and inorganic aerosol compositions in Ulaanbaatar, Mongolia, during the cold winter of 2007 to 2008: Dicarboxylic acids, ketocarboxylic acids, and $\alpha$-dicarbonyls, J. Geophys. Res., 115, D22203, doi:10.1029/2010JD014339, 2010.
Kawamura, K. and Kaplan, I. R.: Motor exhaust emission as a primary source of dicarboxylic acids in Los Angeles ambient air, Environ. Sci. Technol., 21, 105-110, 1987.

Kawamura, K., Kasukabe, H., and Barrie, L. A.: Source and reaction pathways of dicarboxylic acids, ketoacids and dicarbonyls in arctic aerosols: One year of observations, Atmos. Environ., 30, 1709-1722, 1996a.

Kawamura, K., Sempéré, R., Imai, Y., Hayashi, M., and Fujii, Y.: Water soluble dicarboxylic acids and related compounds in the Antarctic aerosols, J. Geophys. Res., 101, 18721-18728, $1996 \mathrm{~b}$.

Kawamura, K., Kobayashi, M., Tsubonuma, N., Mochida, M., Watanabe, T., and Lee, M.: Organic and inorganic compositions of marine aerosols from East Asia: Seasonal variations of water soluble dicarboxylic acids, major ions, total carbon and nitrogen, and stable $\mathrm{C}$ and $\mathrm{N}$ isotopic composition, in Geochemical Investigation in Earth and Space Science; A Tribute to Issac R. Kaplan, The Geochemical Society Special Publication Series, vol. 9, edited by: Hill, R. J., 243-265, Elsevier, Amsterdam, Netherlands, 2004.

Kawamura, K., Kasukabe, H., and Barrie, L. A.: Secondary formation of water-soluble organic acids and $\alpha$-dicarbonyls and their contribution to total carbon and water-soluble organic carbon: Photochemical ageing of organic aerosols in the Arctic spring, $\mathrm{J}$ Geophys. Res., 115, D21306, doi:10.1029/2010JD014299, 2010.

Keene, W. C., Pszenny, A. P., Galloway, J. N., and Hawley, M. E.: Sea-salt corrections and interpretations of constituent ratios in marine precipitation, J. Geophys, Res., 91, 6647-6658, 1986.

Kim, J. C., Kim, K. J., Kim, D. S., and Han, J. S.: Seasonal variations of monoterpene emissions from coniferous trees of different ages in Korea, Chemosphere, 59, 1685-1896, 2005.

Koch, D.: Transport and direct radiative forcing of carbonaceous and sulfate aerosols in the GISS GCM, J. Geophys. Res., 106, 20311-20332, 2001.

Kundu, S., Kawamura, K., and Lee, M.: Seasonal variations of diacids, ketoacids and $\alpha$-dicarbonyls in marine aerosols at Gosan, Jeju Island: Implications for their formation and degradation during long-range transport, J. Geophys. Res., 115, D19307, doi:10.1029/2010JD013973, 2010.

Lee, J. H., Kim, Y. P., Moon, K.-C., Kim, H.-K., and Lee, C. B.: Fine particle measurements at two background sites in Korea between 1996 and 1997, Atmos. Environ., 35, 635-643, 2001.

Limbeck, A., Puxbaum, H., Otter, L., and Scholes, M. C.: Semivolatile behavior of dicarboxylic acids and other polar organic species at a rural background site (Nylsvley, RSA), Atmos. Environ., 35, 1853-1862, 2001.

Lin, J. and Tai, H.: Concentrations and Distributions of Carbonaceous Species in Ambient Particles in Kaohsiung City, Taiwan, Atmos. Environ. 35, 2627-2636, 2001.

Lun, X., Takami, A., Miyoshi, T., and Hatakeyama, S.: Characteristic of organic aerosol in a remote area of Okinawa Island, J. Environ. Sci., 21, 1371-1377, 2009.

Mayol-Bracero, O. L., Guyon, P., Graham, B., Roberts, G., Andreae, M. O., Decesari, S., Facchini, M. C., Fuzzi, S., and Artaxo, P.: Water-soluble organic compounds in biomass burning aerosols over Amazonia: 2. Apportionment of the chemical composition and importance of the polyacidic fraction, J. Geophys Res., 107, 8091, doi:10.1029/2001JD000522, 2002.

McInnes, L. M., Covert, D. S., Quinn, P. K., and Germani, M. S.: Measurements of chloride depletion and sulphur enrichment in 
individual sea-salt particles collected remote marine boundary layer, J. Geophys. Res., 99, 8257-8268, 1994.

Meinert, D. L. and Winchester, J. W.: Chemical relationships in the north Atlantic marine aerosol, J. Geophys. Res., 82, 1778-1782, 1977.

Miyazaki, Y., Kondo, Y., Takegawa, N., Komazaki, Y., Fukuda, M., Kawamura, K., Mochida, M., Okuzawa, K., and Weber, R. J.: Time-resolved measurements of water-soluble organic carbon in Tokyo, J. Geophys. Res., 111, D23206, doi:10.1029/2006JD007125, 2006.

Miyazaki, Y., Kondo, Y., Han, S., Koike, M., Kodama, D., Komazaki, Y., Tanimoto, H., and Matsueda, H.: Chemical characteristics of water-soluble organic carbon in the Asian outflow, J. Geophys. Res., 112, D22S30, doi:10.1029/2007JD009116, 2007.

Miyazaki, Y., Aggarwal S. C., Singh, K., Gupta, K. P., and Kawamura, K.: Dicarboxylic acids and water-soluble organic carbon in aerosols in New Delhi, India, in winter: Characteristics and formation processes, J. Geophys. Res., 114, D19206, doi:10.1029/2009JD011790, 2009.

Miyazaki, Y., Kawamura, K., and Sawano, M.: Size distributions of organic nitrogen and carbon in remote marine aerosols: Evidence of marine biological origin based on their isotopic ratios, Geophys. Res. Lett., 37, L06803, doi:10.1029/2010GL042483, 2010a.

Miyazaki, Y., Kawamura, K., and Sawano, M.: Size distributions and chemical characterization of water-soluble organic aerosols over the western North Pacific in summer, J. Geophys. Res., 115, D23210, doi:10.1029/2010JD014439, 2010b.

Miyazaki, Y., Kawamura, K., Jung, J., Furutani, H., and Uematsu, M.: Latitudinal distributions of organic nitrogen and organic carbon in marine aerosols over the western North Pacific, Atmos. Chem. Phys., 11, 3037-3049, doi:10.5194/acp-11-3037-2011, 2011

Mochida M., Nishita-Hara, C., Furutani, H., Miyazaki, Y., Jung, J., Kawamura, K., and Uematsu, M.: Hygroscopicity and cloud condensation nucleus activity of marine aerosol particles over the western North Pacific, J. Geophys. Res., 116, D06204, doi:10.1029/2010JD014759, 2010.

Nishikawa, M., Hao, Q., and Morita, M.: Preparation and evaluation of certified reference materials from Asian mineral dust, Global Environ. Res. 4, 103-113, 2000.

Novakov, T. and Penner, J. E.: Large contribution of organic aerosols to cloud-condensation-nuclei concentrations, Nature., 365, 823-826, 1993.

Pavuluri, C., M., Kawamura, K., and Swaminathan, T.: Watersoluble organic carbon, dicarboxylic acids, ketoacids, and $\alpha$ dicarbonyls in the tropical Indian aerosols, J. Geophys. Res., 115, D11302, doi:10.1029/2009JD012661, 2010.

Pavuluri, C. M., Kawamura, K., Aggarwal, S. G., and Swaminathan, T.: Characteristics, seasonality and sources of carbonaceous and ionic components in the tropical aerosols from Indian region, Atmos. Chem. Phys., 11, 8215-8230, doi:10.5194/acp-11-82152011, 2011.

Park, S. S., Kim, Y. J., and Fung, K.: $\mathrm{PM}_{2.5}$ carbon measurements in two urban areas: Seoul and Kwangju, Korea, Atmos. Environ., 36, 1287-1297, 2002.

Prospero, J. M.: The chemical and physical properties of marine aerosols: An introduction, in Chemistry of Marine Water and Sediments, edited by A. Gianguzza, E. Pellizzetti, and S. Sam- marano, 35-82, Springer-Verlag Berlin, Heidelberg, Germany, 2002.

Ramanathan, V., Crutzen, P. J., Kiehl, J. T., and Rosenfeld, D.: Aerosols, climate, and the hydrological cycle, Science, 294, 2119-2124, 2001.

Sato, K., Li, H., Tanaka, Y., Ogawa, S., Iwasaki, Y., Takami, A., and Hatakeyama, S.: Long-range transport of particulate polycyclic aromatic hydrocarbons at Cape Hedo remote island site in the East China Sea between 2005 and 2008, J. Atmos. Chem., 61, 243-257, 2009.

Savoie, D. L., Prospero, J. M., Arimoto, R., and Duce, R. A.: Non seasalt sulfate and methanesulfonate at American Samoa, J. Geophys. Res., 99, 3587-3596, 1994

Saxena, P., Hildemann, L., McMurry, P., and Seinfeld, J.: Organics alter hygroscopic behavior of atmospheric particles, J. Geophys. Res., 100, 18755-18770, 1995.

Shaw, S, L., Gantt, B., and Meskhidze, N.: Production and emissions of marine isoprene and monoterpenes:A Review, Advances in Meteorology, 2010, 24 pp., 408696 doi:10.1155/2010/408696, 2010.

Takami, A., Miyoshi, T., Shimono, A., Kaneyasu, N., Kato, S., Kajii, Y., and Hatakeyama, S.: Transport of anthropogenic aerosols from Asia and subsequent chemical toluene, and p-xylene, J. Phys. Chem. A., 105, 7865-7874, 2007.

Tambunan, P., Baba, S., Kuniyoshi, A., Iwasaki, H., Nakamura, T., Yamasaki, H., and Oku, H.: Isoprene emission from tropical trees in Okinawa Island, Japan, Chemosphere, 65, 2138-2144, 2006.

Turpin, B. J. and Huntzicker, J. J.: Secondary Formation of Organic Aerosol in the Los Angeles Basin: A Descriptive Analysis of Organic and Elemental Carbon Concentrations, Atmos. Environ., 25, 207-215, 1991.

Turpin, B. J. and Huntzicker, J. J.: Identification of secondary organic aerosol episodes and quantification of primary and secondary organic aerosol concentrations during SCAQS, Atmos. Environ., 29, 3527-3544, 1995.

Turpin, B. J. and Lim, H.-J.: Species contributions to $\mathrm{PM}_{2.5}$ mass concentrations: Revisiting common assumptions for estimating organic mass, Aerosol Sci. Tech., 35, 602-610, 2001.

Turpin, B. J., Huntzicker, J. J., Larson, S. M., and Cass, G. R.: Los Angeles Summer Midday Particulate Carbon: Primary and Secondary Aerosol, Environ. Sci. Technol., 25, 1788-1793, 1991.

Ueda, S., Osada, K., and Takami, A.: Morphological features of soot-containing particles internally mixed with watersoluble materials in continental outflow observed at Cape Hedo, Okinawa, Japan, J. Geophys. Res., 116, D17207, doi:10.1029/2010JD015565, 2011

Verma, R. L., Kondo, Y., Oshima, N., Matsui, H., Kita, K., Sahu, L. K., Kato, S., Kajii, Y., Takami, A., and Miyakawa, T. Seasonal variations of the transport of black carbon and carbon monoxide from the Asian continent to the western $\mathrm{Pa}$ cific in the boundary layer, J. Geophys. Res., 116, D21307, doi:10.1029/2011JD015830, 2011.

Wedyan, M. A. and Preston, M. R.: The coupling of surface seawater organic nitrogen and the marine aerosol as inferred from enantiomer-specific amino acid analysis, Atmos. Environ., 42, 8698-8705, 2008

Wang, H., Kawamura, K., and Shooter, D.: Carbonaceous and ionic components in wintertime atmospheric aerosols from two New 
Zealand cities: Implication for solid fuel combustion, Atmos. Environ., 39, 5865-5875, 2005.

Wang, G. H., Kawamura, K., Lee, S. C., Ho, K. F., and Cao, J. J.: Molecular, seasonal and spatial distribution of organic aerosols from fourteen Chinese cities, Environ. Sci. Technol., 40, 46194625, 2006.

Wang, H., Kawamura, K., and Shooter, D.: Carbonaceous and ionic components in wintertime atmospheric aerosols from two New Zealand cities: Implication for solid fuel combustion, Atmos. Environ., 39, 5865-5875, 2005.

Wang, G., Kawamura, K., Xie, M., Hu, S., Gao, S., Cao, J., An, Z., and Wang, Z.: Size-distributions of n-alkanes, PAHs and hopanes and their sources in the urban, mountain and marine atmospheres over East Asia, Atmos. Chem. Phys., 9, 8869-8882, 2009, http://www.atmos-chem-phys.net/9/8869/2009/.

Wang, G., Xie, M., Hu, S., Tachibana, E., Kawamura, K.: Dicarboxylic acids, metals and isotopic compositions of $\mathrm{C}$ and $\mathrm{N}$ in atmospheric aerosols from inland China: implications for dust and coal burning emission and secondary aerosol formation, Atmos. Chem. Phys., 2010.

Wang, G., Kawamura, K., Hu, S., Xie, M., Zhou, B., Li, J., Cao, J., and An, Z.: Selected water soluble organic compounds found in size-resolved aerosols collected from the urban, mountain, and marine atmospheres over East Asia, Tellus B, 63, 371-381, 2011.

Wang, Z. B., Hu, M., Yue, D. L., He, L. Y., Huang, X. F., Yang, Q., Zheng, J., Zhang, R. Y., and Zhang, Y. H.: New particle formation in the presence of a strong biomass burning episode at a downwind rural site in PRD, China, Tellus, 65,19965, doi:10.3402/tellusb.v65i0, 2013a.
Wang, G. H., Zhou, B. H., Cheng, C. L., Cao, J. J., Li, J. J., Meng, J. J., Tao, J., Zhang, R. J., and Fu, P. Q.: Impact of Gobi desert dust on aerosol chemistry of Xi' an, inland China during spring 2009: differences in composition and size distribution between the urban ground surface and the mountain atmosphere, Atmos. Chem. Phys., 13, 819-835, doi:10.5194/acp-13-819-2013, 2013b.

Yamamoto, S. and Kawamura, K.: Stable hydrogen isotopic compositions of fossil fuel-derived n-alkanes in the atmospheric aerosols from Okinawa, Japan, Res. Org. Geochem., 27, 81-89, 2011.

Yao, X. and Zhang, L.: Chemical processes in sea-salt chloride depletion observed at a Canadian rural coastal site, Atmos. Environ., 46, 189-194, doi:10.1016/j.atmosenv.2011.09.081, 2012.

Zhang, M., Uno., I., Carmichael, G. R., Akimoto, H., Wang, Z., Tang, Y., Woo, J.-H., Streets, D. G., Sachse, G. W., Avery, M. A., Weber, R. J., and Talbot, R. W.: Large-scale structure of trace gas and aerosol distributions over the western Pacific Ocean during the Transport and Chemical Evolution Over the Pacific (TRACE-P) experiment, J. Geophys. Res., 108, 8820, doi:10.1029/2002JD002946, 2003. 